\title{
Low Temperature Oxidation of Carbon Monoxide over Mesoporous $\mathrm{Au}-\mathrm{Fe}_{2} \mathrm{O}_{3}$ Catalysts
}

\author{
Abdulmohsen Ali Alshehri and Katabathini Narasimharao \\ Department of Chemistry, Faculty of Science, King Abdulaziz University, P.O. Box 80203, Jeddah 21589, Saudi Arabia \\ Correspondence should be addressed to Abdulmohsen Ali Alshehri; aayalshehri@kau.edu.sa
}

Received 5 March 2017; Revised 23 May 2017; Accepted 6 June 2017; Published 10 July 2017

Academic Editor: Felipe A. La Porta

Copyright (C) 2017 Abdulmohsen Ali Alshehri and Katabathini Narasimharao. This is an open access article distributed under the Creative Commons Attribution License, which permits unrestricted use, distribution, and reproduction in any medium, provided the original work is properly cited.

\begin{abstract}
Low temperature active and stable mesoporous $\mathrm{Au}(0.1,0.2,0.5$, and $1.0 \mathrm{wt} . \%)$ supported $\alpha-\mathrm{Fe}_{2} \mathrm{O}_{3}$ catalysts were prepared via deposition-precipitation method. The $\mathrm{H}_{2}$-pretreated catalyst with $0.5 \mathrm{wt}$. \% Au loading offered CO conversion of $100 \%$ at $323 \mathrm{~K}$ and showed continual activity for at least $120 \mathrm{~h}$. X-ray diffraction and transmission electron microscopy analysis indicate that Au species were highly dispersed as nanoparticles $(20-40 \mathrm{~nm})$ on the surface of $\alpha-\mathrm{Fe}_{2} \mathrm{O}_{3}$ support even after thermal treatment at $773 \mathrm{~K}$. The $\mathrm{N}_{2}$-physisorption measurements show that the synthesized $\alpha-\mathrm{Fe}_{2} \mathrm{O}_{3}$ support and $\mathrm{Au}-\mathrm{Fe}_{2} \mathrm{O}_{3}$ nanocomposites possessed mesopores with high specific surface area of about $158 \mathrm{~m}^{2} \mathrm{~g}^{-1}$. X-ray photoelectron spectroscopy and $\mathrm{H}_{2}$-TPR results reveal that the Au species exist in metallic and partially oxidized state due to strong interaction with the support. Effective $\mathrm{Au}-\mathrm{Fe}_{2} \mathrm{O}_{3}$ interaction resulted in a high activity for Au nanoparticles, locally generated by the thermal treatment at $773 \mathrm{~K}$ in air.
\end{abstract}

\section{Introduction}

The activity of humans in the world led to massive production of carbon monoxide (CO), starting from wood burning for warming houses and utilization of fossil fuels for electricity production, automobile engines, and industrial chemical combustion, which involves incomplete oxidation of carbon compounds [1]. In environmental aspects, $\mathrm{CO}$ is a highly toxic gas; high concentration of $\mathrm{CO}$ in the atmosphere is hazardous for lives, and it causes many illnesses, suffocation, and sudden death [2]. $\mathrm{CO}$ is converted to $\mathrm{CO}_{2}$ which is a less toxic and natural gas that exists in the air; $\mathrm{CO}_{2}$ is also a feedstock for methanol production, which in turn is used to produce many chemical compounds that are valuable for human life, such as plastics [3]. In general, the catalyst efficiency in $\mathrm{CO}$ oxidation is determined by its ability to oxidize $\mathrm{CO}$ to $\mathrm{CO}_{2}$ fully at a low reaction temperature. For instance, the catalytic converter used in automobiles exhaust is proposed to oxidize $\mathrm{CO}$ at a temperature lower than $373 \mathrm{~K}$, as it mainly contains traces of precious metals, for instance, palladium, platinum, and rhodium [4]. Au supported catalyst was demonstrated as a highly active catalyst [5]; precious metals are expensive; therefore, enhancement of the support properties plays a key role in catalytic activity, where a small amount of precious metal is doped on a large amount of support. It was reported that transition-metal oxides such as $\mathrm{Fe}_{2} \mathrm{O}_{3}, \mathrm{TiO}_{2}, \mathrm{Co}_{3} \mathrm{O}_{4}$, and $\mathrm{NiO}$ are suitable supports [6]. The bulk $\alpha-\mathrm{Fe}_{2} \mathrm{O}_{3}$ is a reducible support to provide a large amount of active sites; several researchers used $\alpha-\mathrm{Fe}_{2} \mathrm{O}_{3}$ as a support for $\mathrm{CO}$ oxidation. We recently synthesized Ag$\mathrm{Fe}_{2} \mathrm{O}_{3}$ nanocomposites and utilized them as catalysts for $\mathrm{CO}$ oxidation [7]. It was reported that $\alpha-\mathrm{Fe}_{2} \mathrm{O}_{3}$ possessed an advantage in that it has a long lifetime because it could resist poisoning from $\mathrm{CO}_{2}$ [8]. Many research groups [9-13] utilized Au supported iron oxide materials as a catalyst for $\mathrm{CO}$ oxidation. However, the controlled synthesis of Au metal oxide nanocomposites still faces tremendous challenges [14].

The preparation method of $\alpha-\mathrm{Fe}_{2} \mathrm{O}_{3}$ support shows a significant change in support properties such as particle size, morphology, and surface area and their interaction with active metals. Synthesized $\alpha-\mathrm{Fe}_{2} \mathrm{O}_{3}$ nanoparticles showed a much higher activity than microcrystalline $\alpha-\mathrm{Fe}_{2} \mathrm{O}_{3}$ for $\mathrm{CO}$ oxidation; in other words, $\alpha-\mathrm{Fe}_{2} \mathrm{O}_{3}$ could be fabricated in a desired morphology to obtain an efficient catalyst [15]. 
Mesoporous support (in which the pore size ranges between 2 and $50 \mathrm{~nm}$ ) has an advantage to obtain good dispersion of active metal nanoparticles; the mesopores are responsible for capillary condensation and allow active metal nanoparticles to disperse more into the wall of pores [16]. Mesoporous $\mathrm{Fe}_{2} \mathrm{O}_{3}$ was prepared by different methods using templates, such as cellulose nanocrystals template [17] and SBA-15 [18]. Park and Lee [12] observed that oxidized gold species are important for $\mathrm{CO}$ oxidation and the authors concluded that the oxidized gold species were more active than metallic gold. Further, different opinions were reported with respect to the active catalyst that contained both Au atoms and ions $[19,20]$. However, strong evidence of the oxidation states of $\mathrm{Au}$ for achieving high activity is one of the major issues that has not yet been resolved.

In this work, we aim to synthesize nanosized mesoporous $\mathrm{Au}-\mathrm{Fe}_{2} \mathrm{O}_{3}$ composites and use them as catalysts for $\mathrm{CO}$ oxidation at low reaction temperatures. We also made an effort to study the physicochemical properties of the catalysts and correlate the properties with catalytic $\mathrm{CO}$ oxidation activity.

\section{Experimental}

2.1. Preparation of Mesoporous $\alpha-\mathrm{Fe}_{2} \mathrm{O}_{3}$ Nanomaterials. Single-crystalline mesoporous $\alpha-\mathrm{Fe}_{2} \mathrm{O}_{3}$ nanomaterials were obtained by reacting $\mathrm{Fe}\left(\mathrm{NO}_{3}\right)_{3} \cdot 9 \mathrm{H}_{2} \mathrm{O}$ with $\mathrm{NH}_{4} \mathrm{H}_{2} \mathrm{PO}_{4}$ under hydrothermal conditions [21]. Typically, $1.0 \mathrm{~g}$ of $\mathrm{Fe}\left(\mathrm{NO}_{3}\right)_{3} \cdot 9 \mathrm{H}_{2} \mathrm{O}$ was added to $10 \mathrm{~mL}$ of $0.1 \mathrm{~N}$ aqueous $\mathrm{NH}_{4} \mathrm{H}_{2} \mathrm{PO}_{4}$ solution. The added $\mathrm{Fe}\left(\mathrm{NO}_{3}\right)_{3} \cdot 9 \mathrm{H}_{2} \mathrm{O}$ was hydrolyzed within a few minutes, and a brown colored precipitate was formed. The obtained precipitate was stirred for $1 \mathrm{~h}$ and then transferred into an autoclave lined with a Teflon vessel. Then, the autoclave was heated in an electric oven at a temperature of $353 \mathrm{~K}$ for $12 \mathrm{~h}$. After the hydrothermal treatment, the precipitate was washed with distilled water four times, dried in a vacuum oven at $373 \mathrm{~K}$ for $12 \mathrm{~h}$, and calcined at $773 \mathrm{~K}$ for $2 \mathrm{~h}$.

2.2. Preparation of $\mathrm{Au}-\mathrm{Fe}_{2} \mathrm{O}_{3}$ Nanocomposites. Gold was loaded on synthesized $\mathrm{Fe}_{2} \mathrm{O}_{3}$ support via the depositionprecipitation method. In this method, the aqueous suspension containing $1.0 \mathrm{~g}$ of the support material was heated in a water bath at $373 \mathrm{~K}$ and the $\mathrm{pH}$ value of the solution was adjusted to 9.0 by adding $1 \mathrm{~N} \mathrm{NH}_{4} \mathrm{OH}$ solution. A $\mathrm{HAuCl}_{4}$ solution corresponding to Au loading (0.1, 0.2, 0.5, and $1.0 \mathrm{wt} . \%)$ was poured into the suspension. Additional $\mathrm{NH}_{4} \mathrm{OH}$ solution was added dropwise to the suspension to keep the $\mathrm{pH}$ value stable. After stirring for $30 \mathrm{~min}$ and aging for $2 \mathrm{~h}$ at room temperature, the precipitate was filtrated and washed several times with deionized water until no $\mathrm{Cl}^{-}$was detected by a $0.25 \mathrm{~mol} \mathrm{~L}^{-1} \mathrm{AgNO}_{3}$ solution. The resultant precipitate was dried at $393 \mathrm{~K}$ for $3 \mathrm{~h}$ and then calcined at $773 \mathrm{~K}$ for $4 \mathrm{~h}$. The catalysts were denoted as $x \mathrm{Au}-\mathrm{Fe}$, where $x$ represents the Au loading.

2.3. Characterization. The elemental composition of the catalysts was performed using ICP-AES, Optima 7300DV (PerkinElmer Corporation, USA) instrument. The sample preparation procedure for elemental analysis and a detailed description of the experimental procedure were described in our previous publication [22].

The powder X-ray diffraction measurements for the samples were performed using Bruker D8 Advance target diffractometer. The XRD patterns were obtained using $\mathrm{Cu} \mathrm{K} \alpha$ radiation $(\lambda=1.5405 \AA)$ at $40 \mathrm{kV}$ and $40 \mathrm{~mA}$. The identification of phases presented in the samples and crystallite sizes of iron oxide and gold metal were calculated using Scherrer equation as described in our previous publication [22].

Transmission electron microscopy (TEM) and highresolution TEM images of the samples were obtained using a Philips CM200FEG microscope equipped with a field emission gun operated at $200 \mathrm{kV}$. Diffuse reflectance UV-Vis spectra for all the samples were collected using a Thermo Scientific evolution $600 \mathrm{UV}$-visible spectrophotometer conjugated with an integrating sphere in the wavelength range of 200-800 nm.

The textural properties of the synthesized samples were determined from $\mathrm{N}_{2}$ adsorption-desorption measurements at $77 \mathrm{~K}$ carried out using Quantachrome NOVA 3200e automated gas adsorption system. A detailed procedure was described in our previous publication [22] to determine the specific surface area, pore volume, and average pore radius of the samples. The $\mathrm{X}$-ray photoelectron spectroscopy measurements for all the samples were carried out using a SPECS GmbH XPS instrument. A standard dual anode excitation source with $\mathrm{Mg} \mathrm{K} \alpha(1253.6 \mathrm{eV})$ radiation was used at $13 \mathrm{kV}$ and $100 \mathrm{~W} . \mathrm{H}_{2}$-temperature programmed reduction profiles for all the catalyst samples were collected using Quantachrome CHEMBET-3000 instrument. More details of the experimental procedures used in this work can be found in our previous publications [7, 22].

2.4. Catalytic Oxidation of Carbon Monoxide. Catalytic activity measurements for CO oxidation were carried out using a fixed-bed reactor at atmospheric pressure. Quartz spheres $(0.5 \mathrm{~g})$ were used to dilute the $\mathrm{Au}-\mathrm{Fe}_{2} \mathrm{O}_{3}$ catalyst $(0.5 \mathrm{~g})$ in a quartz reactor. Prior to the activity tests, the catalysts were treated with $10 \% \mathrm{H}_{2} / \mathrm{N}_{2}\left(100 \mathrm{~mL} \mathrm{~min}^{-1}\right)$ at $353 \mathrm{~K}$ for 1h. After the catalysts were cooled down to $273 \mathrm{~K}$ under $\mathrm{N}_{2}\left(100 \mathrm{~mL} \mathrm{~min}^{-1}\right)$, the feed gas containing $100 \mathrm{ppm} \mathrm{CO}$ balanced with compressed air was passed through the reactor at $1000 \mathrm{~mL} \mathrm{~min}^{-1}$. The reaction temperature, measured with a thermocouple, was increased from $273 \mathrm{~K}$ to $333 \mathrm{~K}$. Online gas chromatograph (Agilent) with a TCD detector was employed to measure the reactor inlet and outlet gas streams. TDX-01 column $(2 \mathrm{~m} \times 4 \mathrm{~mm})$ was used to separate $\mathrm{O}_{2}, \mathrm{CO}$, and $\mathrm{CO}_{2}$.

The conversion of $\mathrm{CO}$ was by change in $\mathrm{CO}$ concentration:

$$
\text { CO conversion }(\%)=\left\{[\mathrm{CO}]_{\text {inlet }}-\frac{[\mathrm{CO}]_{\text {outlet }}}{[\mathrm{CO}]_{\text {inlet }}}\right\} \times 100 \text {. }
$$

\section{Results and Discussion}

The XRD patterns for pure iron oxide and $\mathrm{Au}-\mathrm{Fe}$ nanocomposite samples are shown in Figure 1. The bulk $\mathrm{Fe}_{2} \mathrm{O}_{3}$ sample 


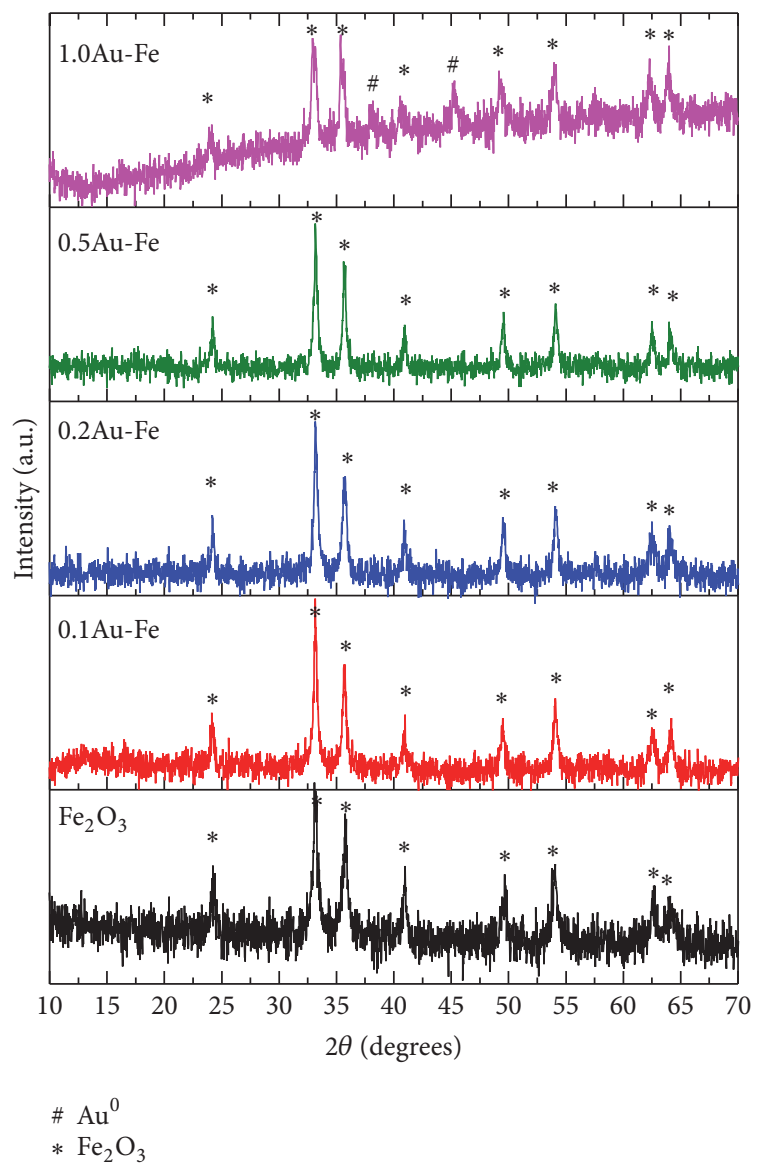

FIGURE 1: XRD patterns of the samples.

calcined at $773 \mathrm{~K}$ showed diffraction peaks at $2 \theta=24.4^{\circ}, 33.5^{\circ}$, $36.0^{\circ}, 41.1^{\circ}, 49.8^{\circ}, 54.7^{\circ}, 57.3^{\circ}, 62.7^{\circ}$, and $64.4^{\circ}$ corresponding to (012), (104), (110), (113), (024), (116), (122), (214), and (300) planes, respectively. These peaks are clearly indexed to $\alpha-\mathrm{Fe}_{2} \mathrm{O}_{3}$ phase [JCPDS number 01-1030]. XRD peaks for the $\alpha-\mathrm{Fe}_{2} \mathrm{O}_{3}$ sample are significantly broader than those for the micrometer sized sample, indicating that the sample possessed a very small particle size. It is also noteworthy that the synthesized sample does not show any diffraction peaks corresponding to any other crystalline phase, indicating the purity of the sample. XRD patterns of the Au-Fe nanocomposites with $0.1,0.2$, and $0.5 \mathrm{wt} . \% \mathrm{Au}$ loadings showed only characteristic diffraction peaks of $\alpha-\mathrm{Fe}_{2} \mathrm{O}_{3}$. Neither Au oxide nor metallic Au was detected at lower Au loading ( $<1.0$ wt.\%). This is possibly due to high dispersion of $\mathrm{Au}$ particles on $\mathrm{Fe}_{2} \mathrm{O}_{3}$ support in lower loadings. The decrease of intensity of diffraction peaks due to $\mathrm{Fe}_{2} \mathrm{O}_{3}$ clearly indicates the decrease of crystallinity of the sample with the increase of Au loading. Additional diffraction peaks can be seen for the $1.0 \mathrm{Au}-$ Fe sample: diffraction peaks at $2 \theta=38.2^{\circ}$ and $2 \theta=44.5^{\circ}$ corresponding to (111) and (200) planes [23] for metallic Au crystallites for the 1.0Au-Fe sample.

The TEM analysis was used to determine the morphology and size of the $\mathrm{Au}$ and $\mathrm{Fe}_{2} \mathrm{O}_{3}$ phases presented in the samples. The TEM images of the Au-Fe nanocomposite samples are
TABLE 1: Crystallite sizes of the samples determined from XRD and TEM measurements.

\begin{tabular}{lcccc}
\hline \multirow{2}{*}{ Catalyst } & \multicolumn{4}{c}{ Crystallite size (nm) } \\
& $\mathrm{Fe}_{2} \mathrm{O}_{3}$ & $\mathrm{Xu}$ & $\mathrm{Fe}_{2} \mathrm{O}_{3}$ & $\mathrm{Au}$ \\
\hline$\alpha-\mathrm{Fe}_{2} \mathrm{O}_{3}$ & $55 \pm 0.3$ & - & 45 & - \\
$0.1 \mathrm{Au}-\mathrm{Fe}$ & $55 \pm 0.4$ & - & 45 & 20 \\
$0.2 \mathrm{Au}-\mathrm{Fe}$ & $54 \pm 0.4$ & - & 45 & 20 \\
$0.5 \mathrm{Au}-\mathrm{Fe}$ & $52 \pm 0.3$ & - & 45 & 15 \\
$1.0 \mathrm{Au}-\mathrm{Fe}$ & $45 \pm 0.4$ & $40 \pm 0.3$ & 42 & 40 \\
\hline
\end{tabular}

presented in Figure 2. It was observed that the synthesized $\alpha$ - $\mathrm{Fe}_{2} \mathrm{O}_{3}$ sample possessed some small cylindrically shaped nanoparticles of about 15-25 nm diameter and 150-200 nm length and also many large particles which are composed of several small cylindrically shaped nanoparticles.

This is possibly due to calcination of the samples at a high reaction temperature leading to several particles bundling together via hydrophilic interactions. Some aggregated spherically shaped $\mathrm{Fe}_{2} \mathrm{O}_{3}$ nanoparticles of size around $50 \mathrm{~nm}$ are also observed along with the cylindrically shaped nanoparticles. The presence of large crystalline particles indicates the formation of polycrystallites, due to the high temperature calcination $(773 \mathrm{~K})$. No clear differences in shape, size, and dispersion of $\mathrm{Au}$ are observed in the $0.1 \mathrm{Au}-\mathrm{Fe}$ and $0.2 \mathrm{Au}-\mathrm{Fe}$ catalysts. However, we must take into account the fact that the loading of $\mathrm{Au}$ in these samples is very low and it makes the detection of Au particles difficult due to the low mass and diffraction contrast. TEM images of $0.5 \mathrm{Au}-\mathrm{Fe}$ and $1.0 \mathrm{Au}-\mathrm{Fe}$ samples clearly show thick black spherical grain of Au metal on the $\alpha-\mathrm{Fe}_{2} \mathrm{O}_{3}$ surface with a size of about $45 \mathrm{~nm}$. Large pores are observed in between the $\alpha-\mathrm{Fe}_{2} \mathrm{O}_{3}$ particles, which is further confirmed by $\mathrm{N}_{2}$ adsorption analysis and discussed in a later part of the Results and Discussion.

The particle size for all the samples was calculated using Scherrer's equation and XRD peak broadening, as shown in Table 1. The half widths of (104) peak of $\alpha-\mathrm{Fe}_{2} \mathrm{O}_{3}$ at $2 \theta=$ $33.5^{\circ}$ and of (111) peak of $\mathrm{Au}$ at $2 \theta=38.2^{\circ}$ (both $\mathrm{Cu} \mathrm{K} \alpha$ ) were used. Scherrer's equation gives the average size in the order of $45 \mathrm{~nm}$ for the $\mathrm{Fe}_{2} \mathrm{O}_{3}$ and $40 \mathrm{~nm}$ for the Au in case of 1.0Au-Fe sample. The XRD determined crystallite sizes of $\alpha$ $\mathrm{Fe}_{2} \mathrm{O}_{3}$ and Au were higher than the crystallite size measured by TEM analysis. Nonuniform particle size distribution could be a reason for such behavior. The average crystal size of $\alpha$ $\mathrm{Fe}_{2} \mathrm{O}_{3}$ was calculated to be $55 \mathrm{~nm}$. The responsible species for the catalytic properties of Au supported catalysts is not clear yet although it was suggested that the interface structures between the Au nanoparticle and metal oxide support act as active sites [24]. In order to understand the interface structure, we carried out high-resolution transmission electron microscopy (HRTEM) analysis for $0.5 \mathrm{Au}-\mathrm{Fe}$ and 1.0AuFe samples. The HRTEM images of both of these samples are shown in Figure 3. It can be seen that there are two lattice fringes with lattice spacings of $0.235 \mathrm{~nm}$ and $0.270 \mathrm{~nm}$ corresponding to the $\mathrm{Au}$ (111) and $\mathrm{Fe}_{2} \mathrm{O}_{3}$ (104) planes from different grains, respectively [25], which further confirm the synthesis of $\mathrm{Au}-\mathrm{Fe}_{2} \mathrm{O}_{3}$ nanocomposite. 

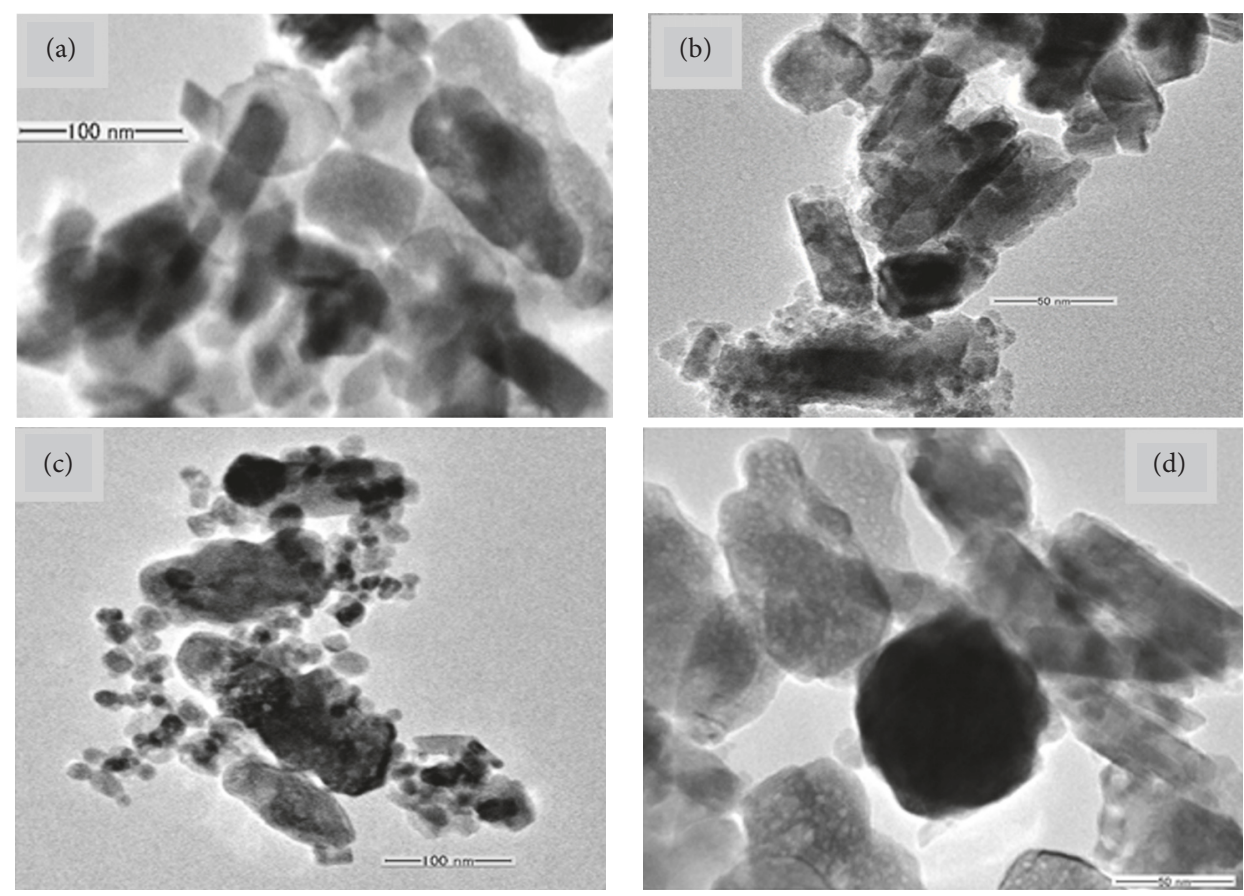

Figure 2: TEM images of (a) 0.1Au-Fe, (b) 0.2Au-Fe, (c) 0.5Au-Fe, and (d) 1.0Au-Fe samples.

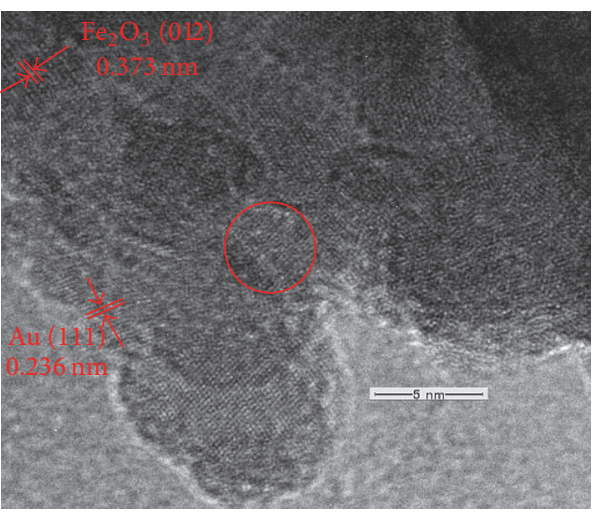

(a)

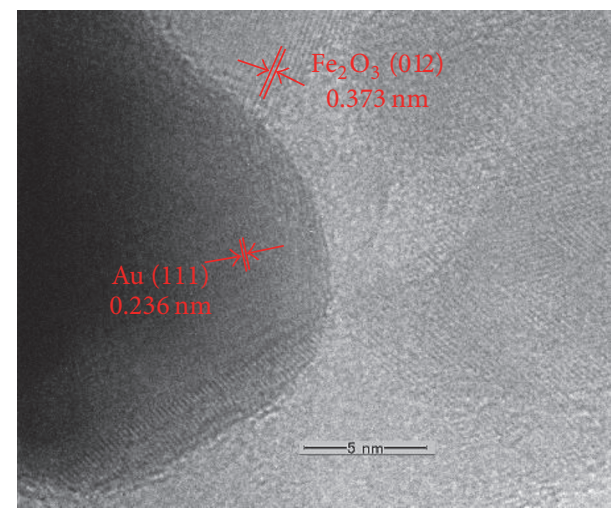

(b)

FIgURE 3: HRTEM images of (a) 0.5Au-Fe and (b) 1.0Au-Fe catalysts.

In case of $1.0 \mathrm{Au}-\mathrm{Fe}$ sample, a large size $\mathrm{Au}$ particle was observed, which might be formed from several smaller particles, and it was deposited on the plain of $\mathrm{Fe}_{2} \mathrm{O}_{3}$ support. The crystal lattices of $\mathrm{Au}$ (111) and $\mathrm{Fe}_{2} \mathrm{O}_{3}$ (104) are distinct and without strong interaction with each other. On the other hand, in the $0.5 \mathrm{Au}-\mathrm{Fe}$ sample, it can be seen that the $\mathrm{Au}$ crystal lattices were overlapped with each other and the $\mathrm{Au}$ particles were surrounded with crystalline $\mathrm{Fe}_{2} \mathrm{O}_{3}$ and a distinct interface between Au particles and $\mathrm{Fe}_{2} \mathrm{O}_{3}$ formed.

The UV-Vis diffuse reflectance spectra of calcined $\mathrm{Fe}_{2} \mathrm{O}_{3}$ and $\mathrm{Au}-\mathrm{Fe}$ nanocomposites are shown in Figure 4. It was reported that iron oxides generally show three kinds of optical transitions. The peaks between 200 and $400 \mathrm{~nm}$ mainly result from the ligand to metal charge transfer transitions and partly from the contribution of the $\mathrm{Fe}^{3+}$ ligand-field transitions.
The region between 400 and $600 \mathrm{~nm}$ is considered to be a result of pair excitation processes, possibly overlapping the contributions of ligand-field transitions [7]. He et al. [26] reported that the peaks in the $600-750 \mathrm{~nm}$ and $750-900 \mathrm{~nm}$ regions could be due to the $d$-d transitions. It is widely known that deposition of the $\mathrm{Au}$ on any support leads to a broad absorption band in the range of $500-570 \mathrm{~nm}$ and this contribution can be assigned to the well-known plasmon resonance of Au nanoparticles [27].

In case of $\mathrm{Au}-\mathrm{Fe}_{2} \mathrm{O}_{3}$ nanocomposite samples, the contribution from $\mathrm{Au}$ nanoparticles was masked by the extended absorption of $\alpha-\mathrm{Fe}_{2} \mathrm{O}_{3}$ in the visible region [28]. However, an increase in the broadness of the Au plasmon absorption band was observed with the increase of Au loading from 0.1 wt.\% to 1.0 wt.\%, although $\mathrm{Au}-\mathrm{Fe}$ nanocomposite samples 
TABLE 2: Elemental composition and textural properties of the catalysts.

\begin{tabular}{|c|c|c|c|c|c|c|c|c|c|}
\hline \multirow[t]{2}{*}{ Catalyst } & \multirow[t]{2}{*}{$\begin{array}{l}\text { Surface area } \\
\qquad\left(\mathrm{m}^{2} \mathrm{~g}^{-1}\right)\end{array}$} & \multirow[t]{2}{*}{$\begin{array}{l}\text { Pore volume } \\
\qquad\left(\mathrm{cc} \mathrm{g}^{-1}\right)\end{array}$} & \multirow[t]{2}{*}{$\begin{array}{l}\text { Pore radius } \\
(\AA)\end{array}$} & \multicolumn{3}{|c|}{$\begin{array}{l}\text { Bulk elemental composition } \\
\text { (ICP analysis) }\end{array}$} & \multicolumn{3}{|c|}{$\begin{array}{c}\text { Surface elemental } \\
\text { composition } \\
\text { (XPS analysis) }\end{array}$} \\
\hline & & & & $\mathrm{Au}$ & $\mathrm{Fe}$ & $\mathrm{Au} / \mathrm{Fe}$ & $\mathrm{Au}$ & $\mathrm{Fe}$ & $\mathrm{Au} / \mathrm{Fe}$ \\
\hline $\mathrm{Fe}_{2} \mathrm{O}_{3}$ & $172 \pm 5$ & 0.316 & 87.7 & - & 41.5 & - & - & 41.4 & - \\
\hline $0.1 \mathrm{Au}-\mathrm{Fe}$ & $168 \pm 3$ & 0.314 & 87.6 & 0.09 & 41.4 & 0.002 & 0.1 & 41.4 & 0.002 \\
\hline $0.2 \mathrm{Au}-\mathrm{Fe}$ & $159 \pm 3$ & 0.273 & 87.7 & 0.18 & 38.4 & 0.005 & 0.2 & 38.6 & 0.004 \\
\hline $0.5 \mathrm{Au}-\mathrm{Fe}$ & $142 \pm 4$ & 0.228 & 87.6 & 0.43 & 36.6 & 0.011 & 0.3 & 36.8 & 0.008 \\
\hline $1.0 \mathrm{Au}-\mathrm{Fe}$ & $118 \pm 3$ & 0.145 & 156.4 & 0.87 & 32.2 & 0.027 & 0.5 & 32.6 & 0.015 \\
\hline
\end{tabular}

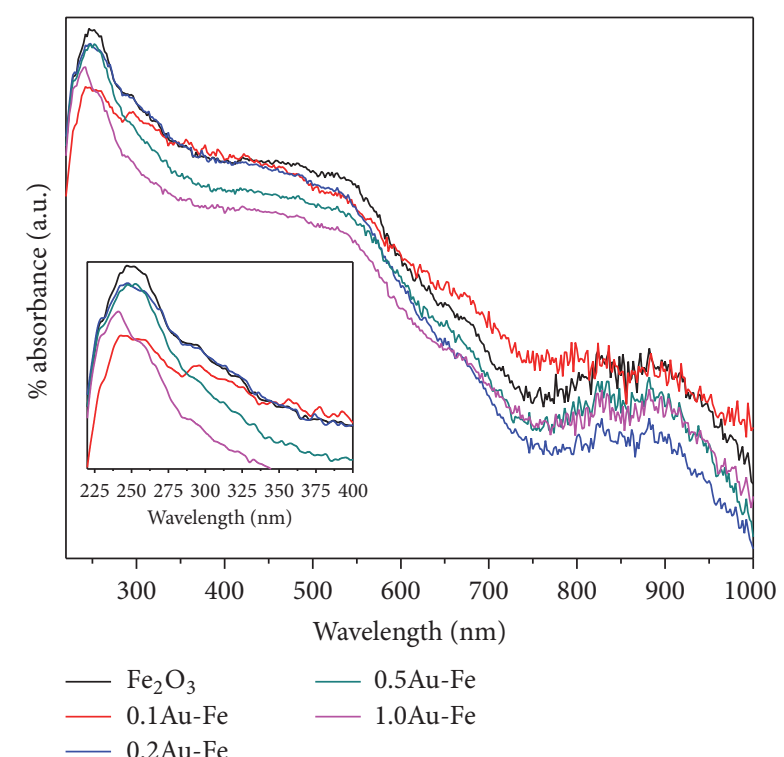

FIgURE 4: UV-Vis diffuse reflectance spectra for all the samples.

display weak plasmon resonance. Furthermore, a red shift was observed as $\mathrm{Au}$ nanoparticles agglomerate on the $\mathrm{Fe}_{2} \mathrm{O}_{3}$ surface in case of $1.0 \mathrm{Au}-\mathrm{Fe}$ sample owing to the relatively big particle size and interparticle interactions. It is possible that the adsorption of oxygen on Au surfaces leads to the formation of surface oxide and forms $\mathrm{Fe}-\mathrm{Au}$ interactive species in the nanocomposite samples.

The textural properties of calcined $\alpha-\mathrm{Fe}_{2} \mathrm{O}_{3}$ and $\mathrm{Au}-$ Fe nanocomposites were studied by the $\mathrm{N}_{2}$-physisorption measurements. The $\mathrm{N}_{2}$ adsorption-desorption isotherms of all the samples are shown in Figure 5. For all the samples, the isotherms are identified as type III according to the IUPAC classification, which is a typical characteristic of macroporous materials [29], and a clear H3-type hysteresis loop is observed, thus indicating the presence of plate-like particles giving rise to slit-shaped pores [30]. The hysteresis loop for the $0.1 \mathrm{Au}-\mathrm{Fe}, 0.2 \mathrm{Au}-\mathrm{Fe}$, and $0.5 \mathrm{Au}-\mathrm{Fe}$ samples is similar to the $\mathrm{Fe}_{2} \mathrm{O}_{3}$ support, thus indicating that the deposition of $\mathrm{Au}$ in low loadings did not modify the macroporous nature of the support. In case of 1.0Au-Fe sample, a similar hysteresis shape was observed; however, the relative pressure where the condensation step occurs shifted to higher $P / P^{0}$ values.
The BET surface area, average pore diameter, and pore volume of all the samples estimated from their respective adsorption-desorption isotherms are given in Table 2. The BET surface area of the calcined macroporous $\alpha-\mathrm{Fe}_{2} \mathrm{O}_{3}$ is $72 \mathrm{~m}^{2} \mathrm{~g}^{-1}$, which is more than 12 times higher than the commercial $\alpha-\mathrm{Fe}_{2} \mathrm{O}_{3}\left(6.0 \mathrm{~m}^{2} \mathrm{~g}^{-1}\right)$. The pore volume of the $\alpha$ $\mathrm{Fe}_{2} \mathrm{O}_{3}$ was found to be $0.316 \mathrm{~cm}^{3} \mathrm{~g}^{-1}$. A decrease of surface area was observed with the increase of $\mathrm{Au}$ loading; this is probably due to the fact that $\mathrm{Au}$ deposition onto $\alpha$ $\mathrm{Fe}_{2} \mathrm{O}_{3}$ makes the pore walls lower than pure $\mathrm{Fe}_{2} \mathrm{O}_{3}$, which is reflected in their surface areas and also confirmed by their respective pore volume and pore radius data.

The pore size distribution (PSD) was obtained by BarrettJoyner-Halenda (BJH) method as shown in Figure 5(b). The porous $\mathrm{Fe}_{2} \mathrm{O}_{3}$ shows unimodal pore size distribution with predominant pore radius of around $87.7 \AA$. It is likely that some Au nanoparticles crystallized inside the pores of $\mathrm{Fe}_{2} \mathrm{O}_{3}$ support during the thermal treatment, thus partially blocking them from the outside, and as a consequence, the mean pore size was shifted to higher values.

X-ray photoelectron spectroscopy (XPS) analysis was utilized to determine the electronic states of elements and composition of the Au-Fe nanocomposites. The XPS spectra of Fe $2 p$, Au $4 f$, and $\mathrm{O} 1 s$ of $\mathrm{Au}-\mathrm{Fe}$ nanocomposite samples are shown in Figure 6. From the figure, it is clear that the $\mathrm{Au} 4 f_{7 / 2}$ peak is weak and $\mathrm{Au} 4 f_{5 / 2}$ is not clearly observed for the $0.1 \mathrm{Au}-\mathrm{Fe}$ sample due to its low Au loading. However, both $\mathrm{Au} 4 f_{7 / 2}$ and $\mathrm{Au} 4 f_{5 / 2}$ peaks were clearly observed after the increase of Au loading (beyond $0.2 \mathrm{wt} \%$ ). It was reported that the $4 f_{7 / 2}$ and $4 f_{5 / 2}$ binding energy values for metallic $\mathrm{Au}^{0}$ are $84.1 \mathrm{eV}$ and $87.7 \mathrm{eV}$. The $\mathrm{Au} 4 f_{7 / 2}$ binding energies for the oxidized $\mathrm{Au}^{+}$and $\mathrm{Au}^{3+}$ ions are $85.6 \mathrm{eV}$ and $86.5 \mathrm{eV}$, respectively [31]. After peak deconvolution of the $\mathrm{Au} 4 f$ energy regions, single $\mathrm{Au} 4 f_{7 / 2}$ and $\mathrm{Au} 4 f_{5 / 2}$ were observed at $83.4 \mathrm{eV}$ and $87.2 \mathrm{eV}$, respectively, for $0.1 \mathrm{Au}-\mathrm{Fe}$, $0.2 \mathrm{Au}-\mathrm{Fe}$, and $0.5 \mathrm{Au}-\mathrm{Fe}$ samples. The binding energy value of $\mathrm{Au} 4 f_{7 / 2}$ observed for these samples is lower than the bulk gold $(84.1 \mathrm{eV})$ indicating the formation of $\mathrm{Au}-\mathrm{Fe}_{2} \mathrm{O}_{3}$ interactive species [11]. A similar observation was reported in the literature $[32,33]$. Further, the binding energy of $\mathrm{Au}$ $4 f$ peaks in the $0.2 \mathrm{Au}-\mathrm{Fe}$ sample is slightly lower than in the $0.1 \mathrm{Au}-\mathrm{Fe}$ and $0.5 \mathrm{Au}-\mathrm{Fe}$ samples. There is probably a stronger interaction between the $\mathrm{Au}$ particles and the $\mathrm{Fe}_{2} \mathrm{O}_{3}$ support in $0.2 \mathrm{Au}-\mathrm{Fe}$ than the other two samples. 


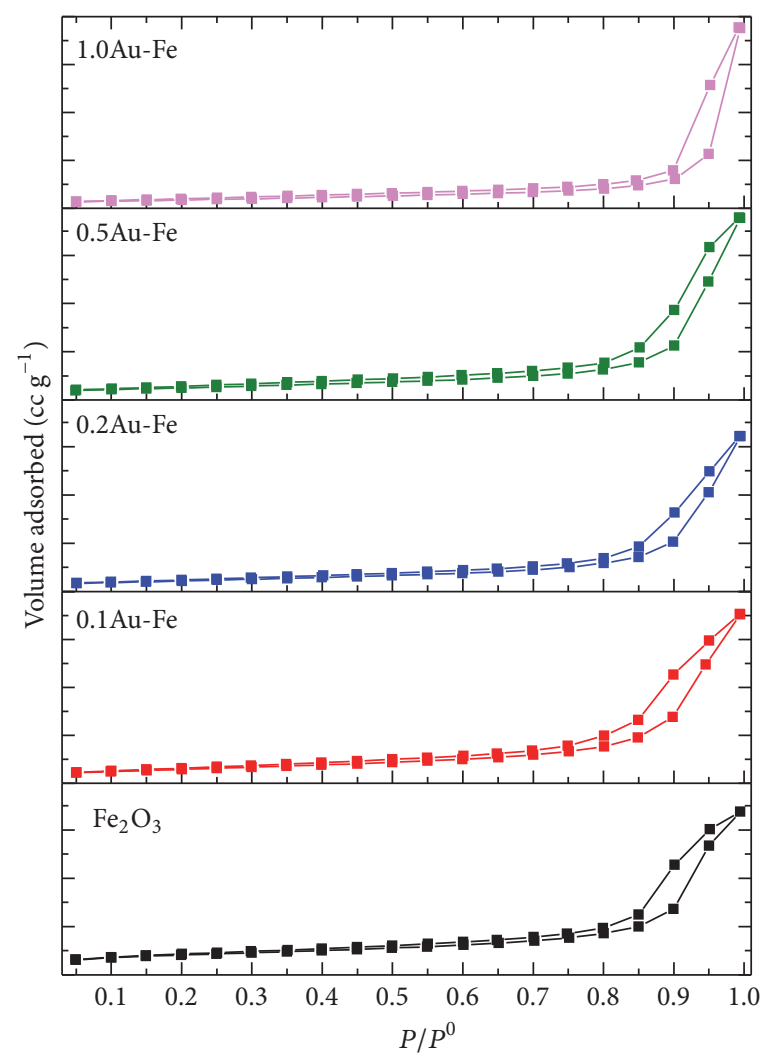

(a)

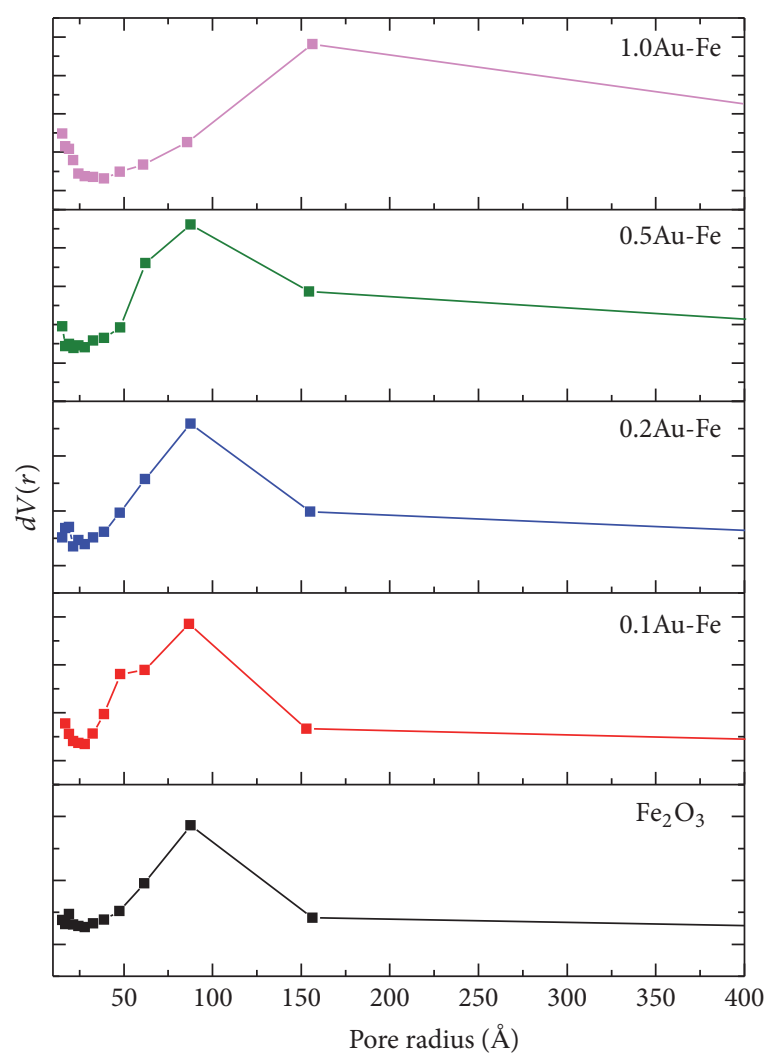

(b)

FIGURE 5: (a) $\mathrm{N}_{2}$ adsorption-desorption isotherms. (b) Pore size distribution patterns of all the samples.

It is interesting to note that, after deconvolution of the $\mathrm{Au} 4 f_{7 / 2}$ energy regions for the 1.0Au-Fe sample, two components at $83.0 \mathrm{eV}$ (I) and $84.3 \mathrm{eV}$ (II) due to metallic Au and oxidized surface Au species were observed [34]. Lin and Chen [35] also observed two distinct peaks of Au supported iron oxide catalysts. The binding energy value of $\mathrm{Au} 4 f_{7 / 2}$ peak (II) is higher than that of $\mathrm{Au}^{0}$ but lower than that of $\mathrm{Au}^{+}$and $\mathrm{Au}^{3+}$. This observation suggests that the oxidized Au species are in the form of $\mathrm{Au}^{\delta+}$, which is a transition state between $\mathrm{Au}^{0}$ and $\mathrm{Au}^{+}$due to the interaction between nanosized $\mathrm{Au}$ particles and the $\mathrm{Fe}_{2} \mathrm{O}_{3}$ support [36]. The XRD patterns of $0.1 \mathrm{Au}-\mathrm{Fe}, 0.2 \mathrm{Au}-\mathrm{Fe}$, and $0.5 \mathrm{Au}-\mathrm{Fe}$ samples did not show any diffraction peaks corresponding to metallic $\mathrm{Au}$, but the XPS analysis of these samples shows the presence of metallic $\mathrm{Au}$ on the support surface. One possible explanation is that the metallic gold formed on the support surface remains largely amorphous in these low loading samples, as amino or nitroso complexes of gold generally get precipitated during the precipitation-deposition method under basic conditions. Upon heating at $393 \mathrm{~K}$, amino or nitroso complexes of gold start to decompose to metallic gold and gold oxides when we calcine the material at $773 \mathrm{~K}$ [11].

It was observed that $\mathrm{Fe}_{2} \mathrm{O}_{3}$ sample showed $\mathrm{Fe} 2 p_{3 / 2}$ peak maxima at $710.6 \mathrm{eV}$ (not shown in Figure 6); some differences were observed in the $\mathrm{Fe} 2 p_{3 / 2}$ binding energy values for $\mathrm{Au}-\mathrm{Fe}$ nanocomposite samples. The $2 p_{3 / 2}$ peak was shifted to higher binding energies $(711.6 \mathrm{eV}$ for $0.1,0.2$, and $0.5 \mathrm{wt} . \% \mathrm{Au}$ and
$711.9 \mathrm{eV}$ for $1.0 \mathrm{wt} . \% \mathrm{Au}$ ), indicating that the Fe oxidation state of surface iron species is sensitive to the Au composition. Brundle [37] reported that, in bulk iron oxides, Fe (III) has a $2 p_{3 / 2}$ binding energy of $711 \mathrm{eV}$, and the $2 p_{3 / 2}$ binding energy of $\mathrm{Fe}(\mathrm{II})$ is centered at $709.7 \mathrm{eV}$. The Fe $2 p$ deconvoluted spectra of all the Au-Fe samples also showed a minor peak located in between $709.2 \mathrm{eV}$ and $708.7 \mathrm{eV}$ and this peak can be attributed to Fe species with lower oxidation state. The appearance of this peak is due to the formation of $\mathrm{Au}-\mathrm{Fe}$ interactive species on the support surface. The contribution of this peak to the $0.2 \mathrm{Au}-\mathrm{Fe}$ sample was $2.2 \%$ and increased to $4.3 \%$ after the loading was increased to $0.5 \mathrm{wt} . \%$. A further increase of Au loading to $1.0 \mathrm{wt} . \%$ caused a decrease in the concentration of this peak to $3.6 \%$. These observations led to the conclusion that the $\mathrm{Au}$ nanoparticles are interacting with $\mathrm{Fe}_{2} \mathrm{O}_{3}$ due to increased dispersion of the $\mathrm{Au}$ metal nanoparticles on the surface of $\mathrm{Fe}_{2} \mathrm{O}_{3}$ support. This statement is supported by the increased $\mathrm{Au} / \mathrm{Fe}$ atomic ratio derived from XPS measurements (Table 2). It is also interesting to note that bulk $\mathrm{Au} / \mathrm{Fe}$ ratio determined from ICP-AES analysis is higher than $\mathrm{Au} / \mathrm{Fe}$ ratio derived from XPS analysis results. This observation indicates that the part of the deposited $\mathrm{Au}$ is transported into the spaces existing in between the $\mathrm{Fe}_{2} \mathrm{O}_{3}$ nanoparticles.

The deconvoluted $\mathrm{O} 1 s$ spectra for all the samples are shown in Figure 6. Three different peaks can be clearly seen in the spectra, which correspond to three different oxygen 

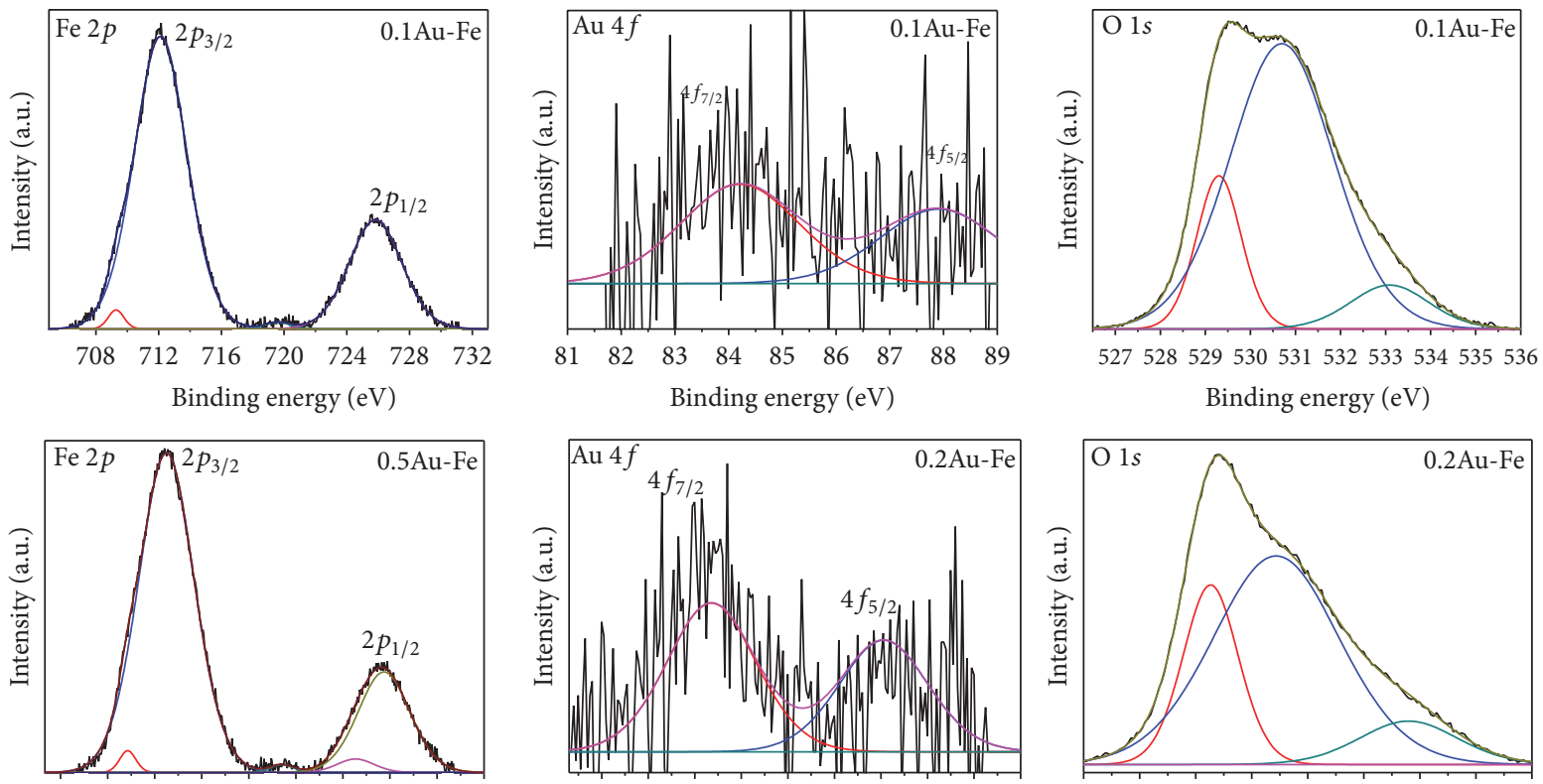

$\begin{array}{llllllllll}705 & 708 & 711 & 714 & 717 & 720 & 723 & 726 & 729 & 732\end{array}$

Binding energy $(\mathrm{eV})$
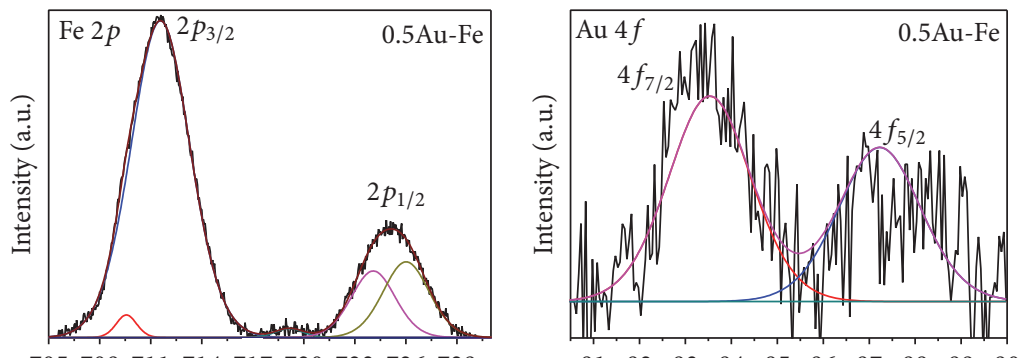

$\begin{array}{llllllllll}81 & 82 & 83 & 84 & 85 & 86 & 87 & 88 & 89 & 90\end{array}$ Binding energy $(\mathrm{eV})$
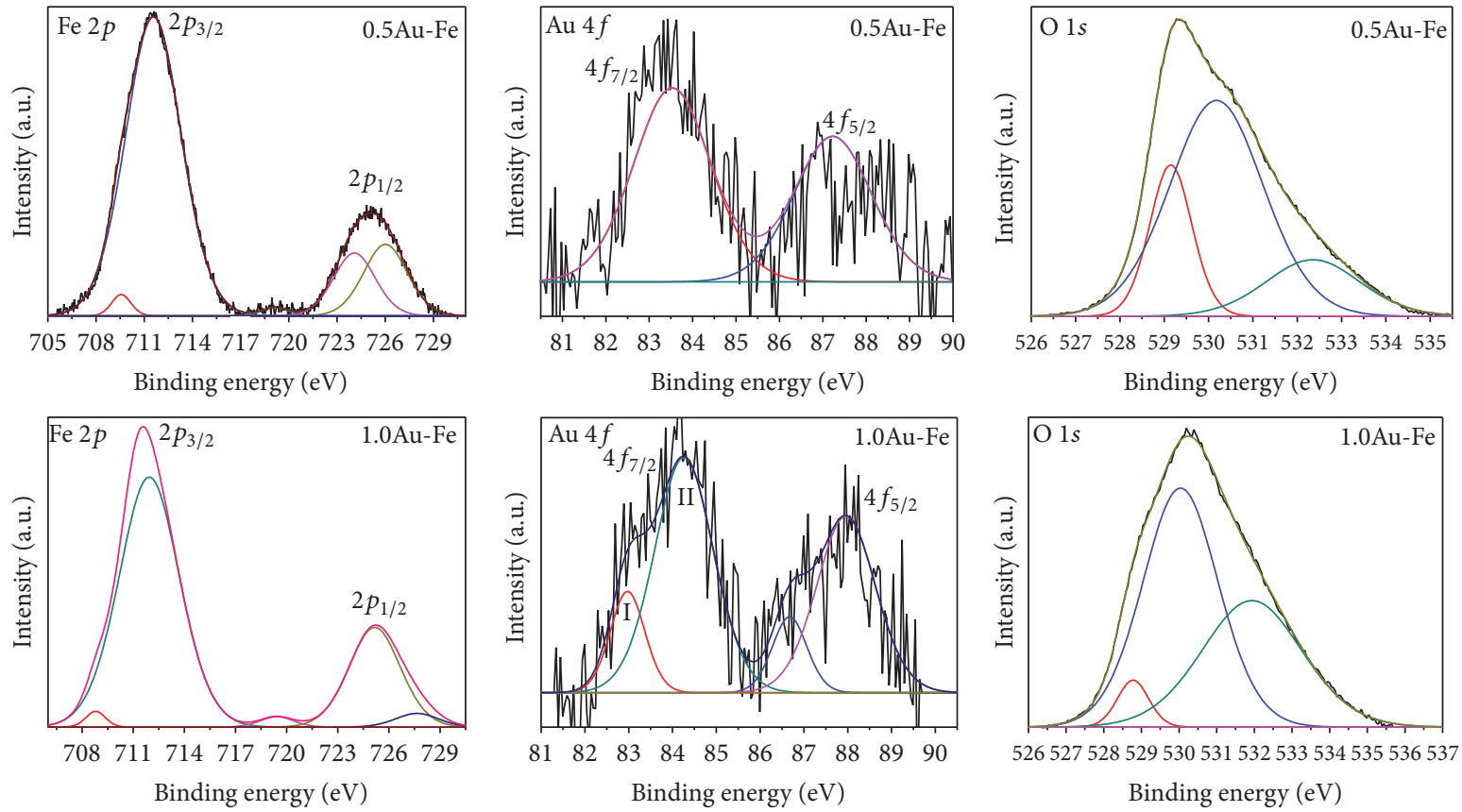

FIGURE 6: XPS spectra for all the samples.

species. The 0.1Au-Fe sample showed peaks at $529.3 \mathrm{eV}$, $531.0 \mathrm{eV}$, and $533.1 \mathrm{eV}$. The peaks at $531.0 \mathrm{eV}$ and $529.3 \mathrm{eV}$ can be attributed to oxygen in $\mathrm{Fe}_{2} \mathrm{O}_{3}$ and $\mathrm{Au}-\mathrm{Fe}_{2} \mathrm{O}_{3}$ interactive species, respectively, while the other peak at $533.1 \mathrm{eV}$ can be related to oxygen in the electrophilic state adsorbed on $\mathrm{Au}$ metal [38]. The relative proportion of the area under the XPS peaks was changed with Au loading (Table S1). The contribution due to the XPS peak at $533.1 \mathrm{eV}$ was increased with the increase of $\mathrm{Au}$ loading from 0.1 to $1.0 \mathrm{wt} . \%$; this observation indicates the increase of Au metal concentration on the $\mathrm{Fe}_{2} \mathrm{O}_{3}$ surface. On the other hand, the contribution due to the $\mathrm{O} 1 \mathrm{~s}$ peak at $529.3 \mathrm{eV}$ was increased up to $0.5 \mathrm{wt} \%$ but decreased upon further increase to $1.0 \mathrm{wt} . \%$. The XPS results are in accordance with the observations from the TEM analysis, and $\mathrm{Au}-\mathrm{Fe}$ nanocomposites possess two types of (Au metal and $\mathrm{Au}-\mathrm{Fe}$ interactive) species and the extent of formation of these species is dependent on the $\mathrm{Au}$ loading over the $\mathrm{Fe}_{2} \mathrm{O}_{3}$ support.

$\mathrm{H}_{2}$-TPR analysis for all the samples was performed to study the reduction behavior and nature of $\mathrm{Au}-\mathrm{Fe}$ interaction 


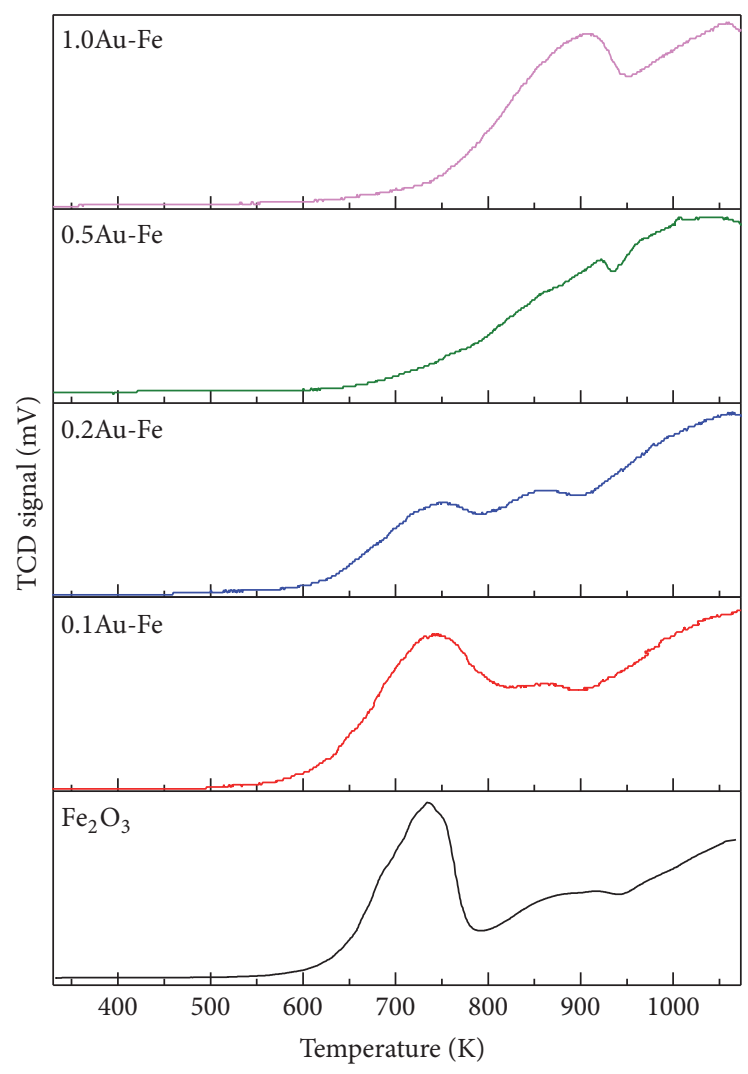

FIGURE 7: $\mathrm{H}_{2}$-TPR patterns for all the samples.

in the $\mathrm{Au}-\mathrm{Fe}$ nanocomposites. Figure 7 shows the $\mathrm{H}_{2}$-TPR spectra of $\alpha-\mathrm{Fe}_{2} \mathrm{O}_{3}$ and $\mathrm{Au}-\mathrm{Fe}$ nanocomposite samples calcined at $773 \mathrm{~K}$. The $\mathrm{H}_{2}$-TPR spectrum of $\alpha-\mathrm{Fe}_{2} \mathrm{O}_{3}$ showed a broad peak that started at $623 \mathrm{~K}$ attributed to the reduction of $\mathrm{Fe}_{2} \mathrm{O}_{3}$ to $\mathrm{Fe}_{3} \mathrm{O}_{4}\left(T_{\max }=723 \mathrm{~K}\right)$ and the other extensive peaks at temperatures beyond $773 \mathrm{~K}$. It was reported that, in the literature [39], the $\mathrm{H}_{2}-\mathrm{TPR}$ peak that appeared at $573 \mathrm{~K}$ can be attributed to the reduction of the hydroxylated $\mathrm{Fe}_{2} \mathrm{O}_{3}$ species and the peak at $\approx 673 \mathrm{~K}$ can be attributed to the reduction of $\mathrm{Fe}_{2} \mathrm{O}_{3}$ to $\mathrm{Fe}_{3} \mathrm{O}_{4}$. The reduction of $\mathrm{Fe}_{3} \mathrm{O}_{4}$ to $\mathrm{FeO}$ occurs at $\approx 873 \mathrm{~K}$ and finally the reduction to $\mathrm{Fe}^{0}$ happens above $1073 \mathrm{~K}$. We can also observe that the high temperature peak does not reach the baseline in the $\mathrm{H}_{2}$-TPR profile of bulk $\mathrm{Fe}_{2} \mathrm{O}_{3}$ sample even at $1073 \mathrm{~K}$, which means the reduction was continued above this temperature.

The $\mathrm{H}_{2}$-TPR patterns for the $0.1 \mathrm{Au}-\mathrm{Fe}$ and $0.2 \mathrm{Au}-\mathrm{Fe}$ nanocomposite samples are very similar to the bulk $\mathrm{Fe}_{2} \mathrm{O}_{3}$ sample; however, deposition of a small amount of Au resulted in a shift in $T_{\max }$ of the peak due to reduction of $\mathrm{FeO}$ to Fe and also the high temperature peak started reaching the baseline in case of $0.2 \mathrm{Au}-\mathrm{Fe}$ sample. This observation reveals that deposition of small amounts of Au could enhance the reduction of $\mathrm{Fe}_{2} \mathrm{O}_{3}$. On the other hand, the $\mathrm{H}_{2}$-TPR spectra of $0.5 \mathrm{Au}-\mathrm{Fe}$ and $1.0 \mathrm{Au}-\mathrm{Fe}$ samples substantially differ from the other samples. Increasing of Au loading to 0.5 and $1.0 \mathrm{wt} . \%$ resulted in the disappearance of the reduction peak at $T_{\max }=$ $723 \mathrm{~K}$ (reduction of $\mathrm{Fe}_{2} \mathrm{O}_{3}$ to $\mathrm{Fe}_{3} \mathrm{O}_{4}$ ). Carabineiro et al. [40] reported similar results that $\mathrm{Au}$ supported $\mathrm{Fe}_{2} \mathrm{O}_{3}$ catalysts showed two reduction peaks above $800^{\circ} \mathrm{C}$, which could be due to the reduction of $\mathrm{Fe}_{3} \mathrm{O}_{4}$ to $\mathrm{FeO}$ (or of $\mathrm{FeO}$ to $\mathrm{Fe}$ ). The deposition of a larger amount of $\mathrm{Au}$ leads to the formation of agglomerated $\mathrm{Au}$ nanoparticles, which interact with $\mathrm{Fe}_{2} \mathrm{O}_{3}$ leading to a shift in reduction temperature. Venugopal and Skurrell [41] also observed a shift in reduction temperature due to the interaction between the Au species and iron oxide support.

The $\mathrm{H}_{2}$ uptake values during the different reduction stages are calculated from integrating the area of the reduction peaks, which are tabulated in Table S2. The overall $\mathrm{H}_{2}$ consumption of the reduction peaks can be assigned to the reduction of $\alpha-\mathrm{Fe}_{2} \mathrm{O}_{3}$ to $\mathrm{Fe}_{3} \mathrm{O}_{4}$ and also the reduction of $\mathrm{Fe}_{3} \mathrm{O}_{4}$ to $\mathrm{Fe}$. In the two stages of reduction, $\mathrm{Fe}_{2} \mathrm{O}_{3}$ reacted with hydrogen based on the following reactions.

$$
\begin{aligned}
& 3 \mathrm{Fe}_{2} \mathrm{O}_{3}+\mathrm{H}_{2} \rightarrow 2 \mathrm{Fe}_{3} \mathrm{O}_{4}+\mathrm{H}_{2} \mathrm{O} ; \mathrm{mol} \mathrm{H}_{2} / \mathrm{mol} \mathrm{Fe}=0.166 \\
& \text { for complete reduction } \\
& \mathrm{Fe}_{3} \mathrm{O}_{4}+4 \mathrm{H}_{2} \rightarrow 3 \mathrm{Fe}+4 \mathrm{H}_{2} \mathrm{O} ; \mathrm{mol} \mathrm{H} \mathrm{H}_{2} / \mathrm{mol} \mathrm{Fe}=1.33 \\
& \text { for complete reduction }
\end{aligned}
$$

The $\mathrm{H}_{2}$ consumption value observed for bulk $\mathrm{Fe}_{2} \mathrm{O}_{3}$ is consistent with the theoretical value. However, the overall $\mathrm{H}_{2}$ consumption observed for $\mathrm{Au}-\mathrm{Fe}$ nanocomposite samples is higher than the stoichiometric amount required to reduce all the Fe presented in the catalyst, indicating that some degree of surface reduction of catalyst takes place at high temperatures as a result of $\mathrm{Au}-\mathrm{Fe}$ interaction in these catalysts.

A fixed-bed catalytic reactor was used to evaluate the catalytic activity of synthesized bulk $\mathrm{Fe}_{2} \mathrm{O}_{3}$ and $\mathrm{Au}-\mathrm{Fe}$ nanocomposite samples. The reactions were conducted at the temperature range of $273-333 \mathrm{~K}$ isothermally. Figures $8(\mathrm{a})$ and $8(\mathrm{~b})$ show the catalytic activity in $\mathrm{CO}$ oxidation of calcined and $\mathrm{H}_{2}$-pretreated catalysts, respectively. In case of calcined catalysts (Figure 8(a)), 100\% CO conversion was observed for $0.5 \mathrm{Au}-\mathrm{Fe}$ catalyst at $313 \mathrm{~K}$, whereas $\mathrm{CO}$ conversion levels corresponded to $97 \%, 92 \%$, and $41 \%$ for 1.0Au-Fe, $0.2 \mathrm{Au}-\mathrm{Fe}$, and $0.1 \mathrm{Au}-\mathrm{Fe}$ catalysts, respectively. The bulk $\mathrm{Fe}_{2} \mathrm{O}_{3}$ support did not show any $\mathrm{CO}$ conversion at the same temperature.

The CO oxidation catalytic activity results obtained for the $\mathrm{H}_{2}$-pretreated catalysts are shown in Figure 8(b). At lower reaction temperatures, for instance, $283 \mathrm{~K}$, the catalysts showed a very little difference in CO conversion (78\%-0.1Au$\mathrm{Fe}, 80 \%-0.2 \mathrm{Au}-\mathrm{Fe}, 83 \%-0.5 \mathrm{Au}-\mathrm{Fe}$, and $78 \%-1.0 \mathrm{Au}-\mathrm{Fe})$. The $\mathrm{CO}$ conversion increased to $100 \%$ at $323 \mathrm{~K}$ for all $\mathrm{Au}-\mathrm{Fe}$ nanocomposite samples. The much higher performances of the $\mathrm{H}_{2}$-pretreated Au-Fe nanocomposite samples could be due to the well dispersed $\mathrm{Au}$ nanoparticles and $\mathrm{Au}-\mathrm{Fe}_{2} \mathrm{O}_{3}$ interactive species [42]. It is known that the well dispersed Au nanoparticles could weaken $\mathrm{C}-\mathrm{O}$ and $\mathrm{O}-\mathrm{O}$ bonds after $\mathrm{CO}$ and $\mathrm{O}_{2}$ adsorption, influencing the interaction between the surface and the adsorbents and favoring CO activation [43].

The influence of Au loading on $\mathrm{CO}$ conversion for the calcined and $\mathrm{H}_{2}$-pretreated $\mathrm{Au}$-Fe nanocomposite catalysts is shown in Figure 8. It is clear that the CO conversion was enhanced when the Au loading was increased from 0.1 to $0.5 \mathrm{wt} . \%$ and then decreased upon further increase of $\mathrm{Au}$ loading to $1.0 \mathrm{wt} . \%$. In case of calcined $\mathrm{Au}-\mathrm{Fe}$ nanocomposite 


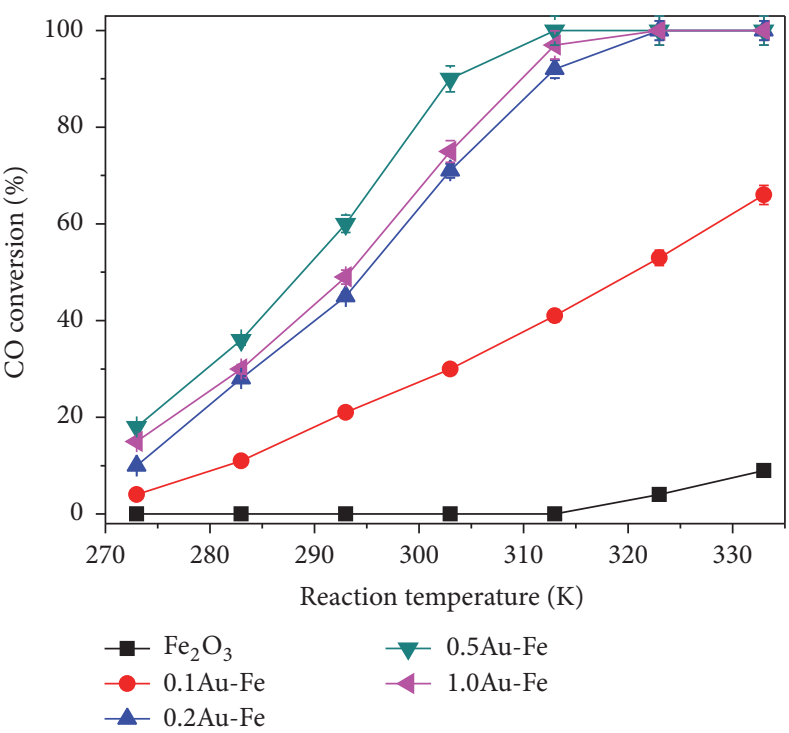

(a)

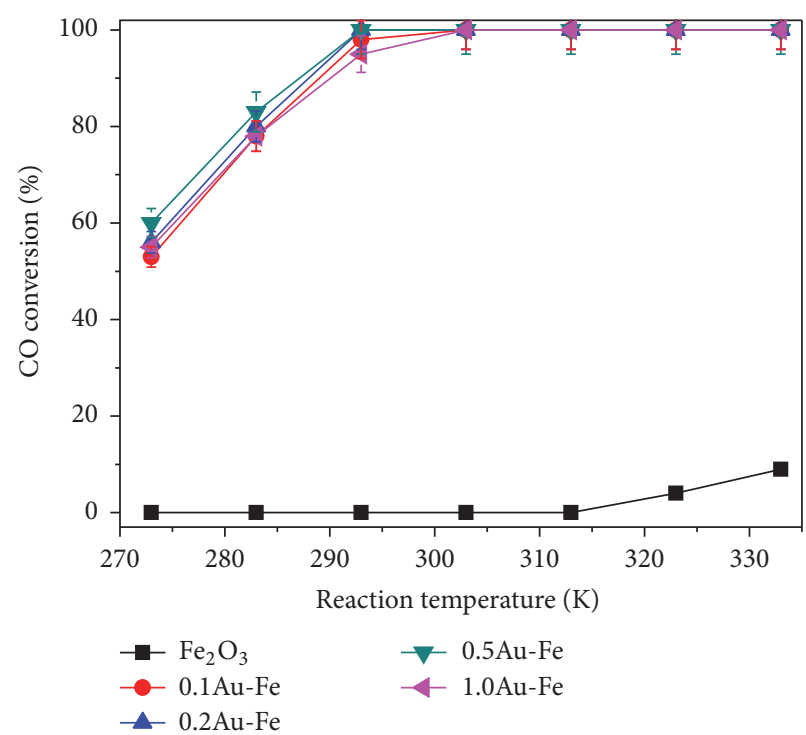

(b)

Figure 8: Catalytic activity in $\mathrm{CO}$ oxidation over (a) calcined $\mathrm{Au}-\mathrm{Fe}$ and (b) $\mathrm{H}_{2}$-treated $\mathrm{Au}-\mathrm{Fe}$ nanocomposite catalysts (reaction conditions: weight of catalyst $0.5 \mathrm{~g}$; total flow rate $1000 \mathrm{~mL} \mathrm{~min}^{-1}$; feed composition $100 \mathrm{ppm} \mathrm{CO/air;} \mathrm{GHSV}=120,000 \mathrm{~mL} \mathrm{~g}^{-1} \mathrm{~h}^{-1}$ ).

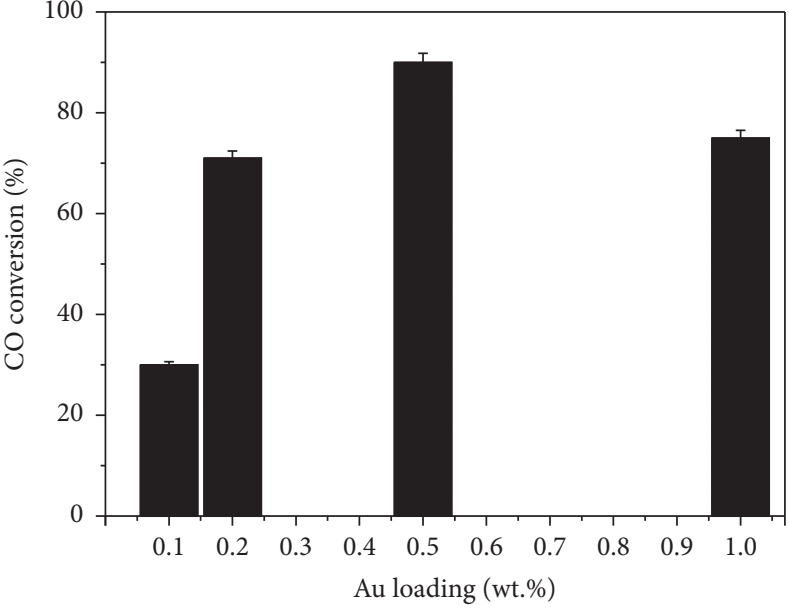

(a)

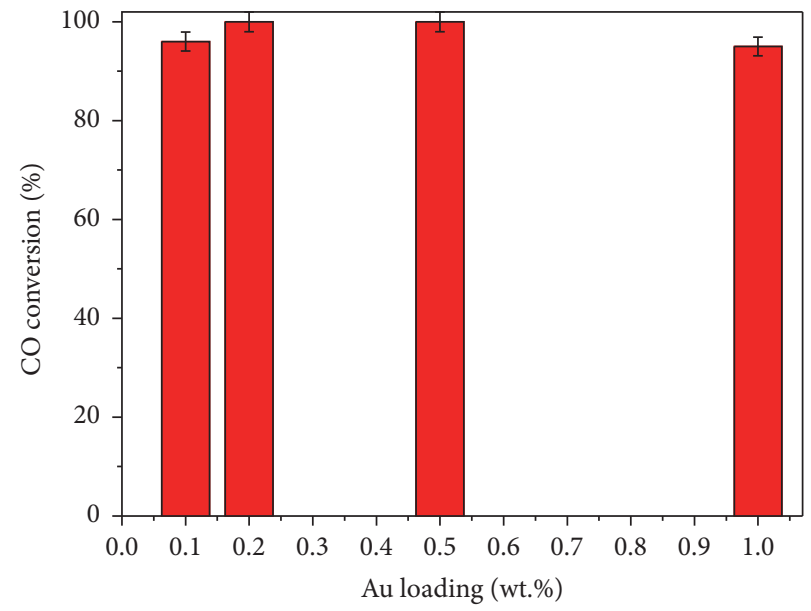

(b)

Figure 9: The influence of $\mathrm{Au}$ loading on $\mathrm{CO}$ conversion over the (a) calcined and (b) $\mathrm{H}_{2}$-treated Au-Fe nanocomposite catalysts (reaction conditions: temperature $293 \mathrm{~K}$; weight of catalyst $0.5 \mathrm{~g}$; total flow rate $1000 \mathrm{~mL} \mathrm{~min}^{-1}$; feed composition $100 \mathrm{ppm} \mathrm{CO/air;} \mathrm{GHSV}$ $=120,000 \mathrm{~mL} \mathrm{~g}^{-1} \mathrm{~h}^{-1}$ ).

samples, the CO conversion was increased from $30 \%$ to $90 \%$ when Au loading was increased from $0.1 \mathrm{wt} . \%$ to $0.5 \mathrm{wt} . \%$ but decreased to $75 \%$ upon further increase to $1.0 \mathrm{wt} . \%$. A similar behavior was observed for $\mathrm{H}_{2}$-pretreated catalysts. These results could be explained on the basis of low $\mathrm{Au}$ particle size, high dispersion of Au metal active sites for $\mathrm{CO}$ adsorption, and activation in case of $0.5 \mathrm{Au}-\mathrm{Fe}$ catalyst, but agglomeration of Au nanoparticles was observed in case of 1.0Au-Fe catalyst.

Figure 9 represents the influence of GHSV on CO conversion over the calcined and $\mathrm{H}_{2}$-pretreated $0.5 \mathrm{Au}$-Fe catalyst; higher space velocity resulted in lower $\mathrm{CO}$ conversion and a similar behavior was observed in all the catalysts. This behavior is expected due to decreased reactants residence time on the catalyst surface with increased GHSV. In case of calcined $0.5 \mathrm{Au}-\mathrm{Fe}$ catalyst, the $\mathrm{CO}$ conversion was decreased from $90 \%$ to $74 \%$ after the GHSV was increased from $60,000 \mathrm{~mL} \mathrm{~g}^{-1} \mathrm{~h}^{-1}$ to $120,000 \mathrm{~mL} \mathrm{~g}^{-1} \mathrm{~h}^{-1}$; however, the extent of decrease is low in case of $\mathrm{H}_{2}$-pretreated catalyst; the CO conversion was decreased from $100 \%$ to $93 \%$. The CO oxidation activity results suggested that $\mathrm{H}_{2}$ pretreatment greatly enhances the reaction rate.

A specific rate for $\mathrm{CO}$ oxidation for calcined $0.5 \mathrm{Au}-$ Fe catalyst was calculated and compared with reaction 
TABLE 3: Specific rates of CO conversion and TOF data for Au supported catalysts from this work and literature reports.

\begin{tabular}{|c|c|c|c|c|c|}
\hline Catalyst & $\begin{array}{c}\text { Au loading } \\
\text { (wt.\%) }\end{array}$ & $\begin{array}{c}\text { Specific rate } \times 10^{-2} \\
\left(\mathrm{~mol}_{\mathrm{CO}} \mathrm{g}_{\mathrm{Au}}{ }^{-1} \mathrm{~h}^{-1}\right)\end{array}$ & $\begin{array}{c}\text { TOF } \times 10^{2} \\
\left(\mathrm{~s}^{-1}\right)\end{array}$ & $\begin{array}{c}\text { Reaction temperature } \\
(\mathrm{K})\end{array}$ & Reference \\
\hline $\mathrm{Au} / \mathrm{La}_{2} \mathrm{O}_{3}$ & 0.5 & $4.0 \pm 0$ & $1.0 \pm 0$ & 298 & {$[44]$} \\
\hline $\mathrm{Au} / \mathrm{CeO}_{2}$ & 5.0 & $2.8 \pm 0$ & $4.7 \pm 0$ & 273 & {$[45]$} \\
\hline $\mathrm{Au} / \mathrm{Fe}-\mathrm{SiO}_{2}$ & 2.0 & $0.7 \pm 0$ & $2.2 \pm 0$ & 273 & {$[46]$} \\
\hline $\mathrm{Au} / \mathrm{SiO}_{2}$ & 1.0 & $0.08 \pm 0$ & $0.03 \pm 0$ & 300 & [47] \\
\hline $\mathrm{Au} / \mathrm{Fe}_{2} \mathrm{O}_{3}$-nanorod & 0.5 & $3.6 \pm 0$ & $4.0 \pm 0$ & 303 & {$[21]$} \\
\hline $\mathrm{Au} / \mathrm{Fe}_{2} \mathrm{O}_{3}$-Fluka & 0.5 & $1.2 \pm 0$ & $2.1 \pm 0$ & 303 & {$[21]$} \\
\hline $\mathrm{Au} / \mathrm{Fe}_{2} \mathrm{O}_{3}$-WGC & 0.5 & $1.7 \pm 0$ & $2.5 \pm 0$ & 303 & {$[40]$} \\
\hline $\mathrm{Au} / \mathrm{Fe}_{2} \mathrm{O}_{3}$-nanocomposite & 0.5 & $12.4 \pm 0.07$ & $5.3 \pm 0.05$ & $293 \pm 1$ & Present work \\
\hline
\end{tabular}

rates of different $\mathrm{Au}$ supported catalysts reported in the literature under similar reaction conditions (Table 3). The calcined $0.5 \mathrm{Au}-\mathrm{Fe}$ catalyst showed a relatively high specific rate of $5.3 \times 10^{-2} \mathrm{~mol}_{\mathrm{CO}} \mathrm{g}_{\mathrm{Au}}^{-1} \mathrm{~h}^{-1}$, which was more active than $\mathrm{Au}-\mathrm{La}_{2} \mathrm{O}_{3}$ catalyst, which possessed a specific rate of $4.0 \times 10^{-2} \mathrm{~mol}_{\mathrm{CO}} \mathrm{g}_{\mathrm{Au}}{ }^{-1} \mathrm{~h}^{-1}$. The $\mathrm{H}_{2}$ pretreatment enhanced the activity further, and the specific rate over the $\mathrm{H}_{2}$-pretreated $0.5 \mathrm{Au}$-Fe catalyst was increased to $12.4 \times$ $10^{-2} \mathrm{~mol}_{\mathrm{CO}} \mathrm{g}_{\mathrm{Au}}{ }^{-1} \mathrm{~h}^{-1}$, which was higher than that of the Au$\mathrm{Fe}_{2} \mathrm{O}_{3}$ catalyst $\left(9.1 \times 10^{-2} \mathrm{~mol}_{\mathrm{CO}} \mathrm{g}_{\mathrm{Au}}^{-1} \mathrm{~h}^{-1}\right)$ prepared by the deposition-precipitation method [21,44-47]. These results clearly indicate the superior catalytic activity of Au-Fe nanocomposite catalysts for CO oxidation.

The turnover frequencies (TOFs) were also calculated in order to gain an insight into the intrinsic activities of $\mathrm{Au}-\mathrm{Fe}$ nanocomposite catalysts. The TOF of $\mathrm{H}_{2}$-pretreated $0.5 \mathrm{Au}-\mathrm{Fe}$ catalyst was $0.038 \mathrm{~s}^{-1}$, exhibiting a significantly higher activity than that of calcined $0.5 \mathrm{Au}-\mathrm{Fe}$ catalyst (TOF $=0.012 \mathrm{~s}^{-1}$ ). The TOF of the $\mathrm{H}_{2}$-pretreated $0.5 \mathrm{Au}$-Fe catalyst was comparable to that of the $\mathrm{Au} / \mathrm{CeO}_{2}$ catalyst $(\mathrm{TOF}=$ $0.047 \mathrm{~s}^{-1}$ ) [45] and the commercial $\mathrm{Au} / \mathrm{Fe}_{2} \mathrm{O}_{3}$ catalyst (TOF $=0.04 \mathrm{~s}^{-1}$ ) [21]. The TOF values of $\mathrm{H}_{2}$-pretreated $\mathrm{Au}-\mathrm{Fe}$ nanocomposite catalysts are higher than of the nanosized $\mathrm{Au}-$ $\mathrm{Fe}_{2} \mathrm{O}_{3}$ catalysts reported in the literature [21]. The enhanced activity of the catalyst could be attributed to the small size of the synthesized Au nanoparticles [48] and also the synthesized nanosized mesoporous $\mathrm{Fe}_{2} \mathrm{O}_{3}$ support possessed a high surface area. As a result, there is an increase in the amount of active sites for the $\mathrm{CO}_{2}$ to adsorb. The oxygen adsorbs to the support and dissociates [49]. The stability of most active catalysts among the investigated samples was tested at $293 \mathrm{~K}$ and the time on stream analysis of the $0.5 \mathrm{Au}-$ Fe sample is shown in Figure 10. The CO conversion was readily decreased from $60 \%$ to $53 \%$ for $0.5 \mathrm{Au}-\mathrm{Fe}$ calcined catalyst after $3 \mathrm{~h}$ and it was further decreased to $50 \%$ after $10 \mathrm{~h}$. The initial $\mathrm{CO}$ conversion of $\mathrm{H}_{2}$-pretreated $0.5 \mathrm{Au}$-Fe catalyst is $100 \%$, and the CO conversion was decreased with the time on stream. After $10 \mathrm{~h}, \mathrm{CO}$ conversion was about $94 \%$.

The stability test further evidenced the highest performance of $\mathrm{H}_{2}$-pretreated $0.5 \mathrm{Au}-\mathrm{Fe}$ catalyst (Figure 11). The $\mathrm{XRD}$ analysis of spent catalyst indicated that sintering of $\mathrm{Au}$ or $\mathrm{Fe}_{2} \mathrm{O}_{3}$ did not occur during the time on stream analysis

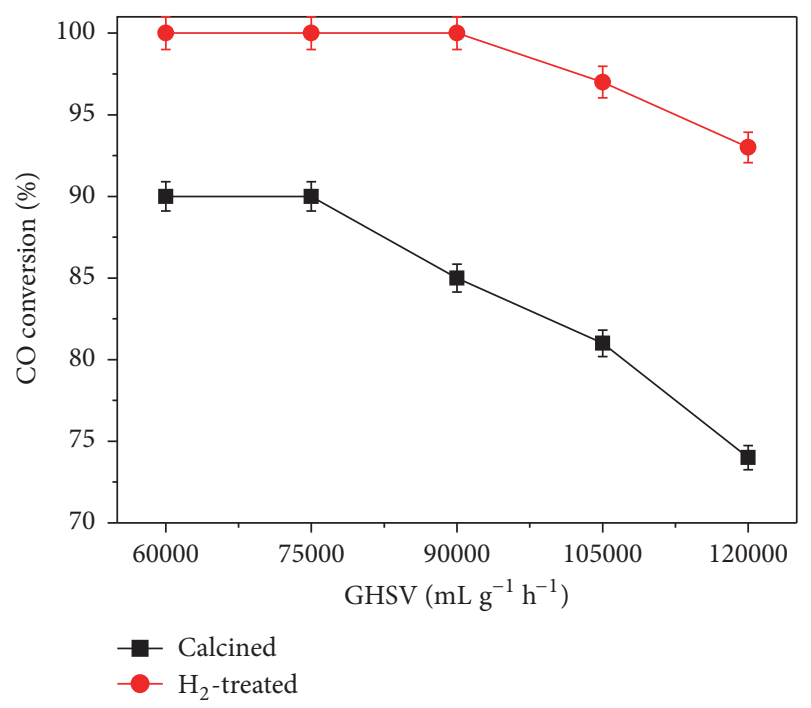

FIGURE 10: The influence of GHSV on CO conversion over the calcined and $\mathrm{H}_{2}$-treated $0.5 \mathrm{Au}-\mathrm{Fe}$ catalyst (reaction conditions: temperature $303 \mathrm{~K}$; weight of catalyst $0.5 \mathrm{~g}$; total flow rate $1000 \mathrm{~mL} \mathrm{~min}^{-1}$; feed composition $100 \mathrm{ppm} \mathrm{CO/air).}$

because the reaction temperature and reduction temperature were lower than the calcination temperature. The slight deactivation observed in the Au-Fe nanocomposite samples is probably due to deposition of carbonate and carbonyl species on the surface of the catalyst.

It is clear that Au-Fe composite samples possessed catalytically active species and they offer a high activity from the beginning and are stable during catalytic tests. The nature of $\mathrm{Au}$ and $\mathrm{Fe}_{2} \mathrm{O}_{3}$ species responsible for the observed activity could be explained on the basis of characterization results. It was widely reported that properties of catalysts, such as particle size, active metal dispersion, surface area, and strength of interaction, have a great influence on the redox properties and reactivity [50]. The behavior of Au supported catalysts was mainly attributed to the electronic interaction between the $\mathrm{Au}$ and support [51] as well as the contribution from $\mathrm{H}_{2}$ pretreatment prior to the reaction.

It is clear that a dispute exists in the literature concerning the role of $\mathrm{Fe}_{2} \mathrm{O}_{3}$ support and active $\mathrm{Au}$ species in $\mathrm{Au} / \mathrm{Fe}_{2} \mathrm{O}_{3}$ 


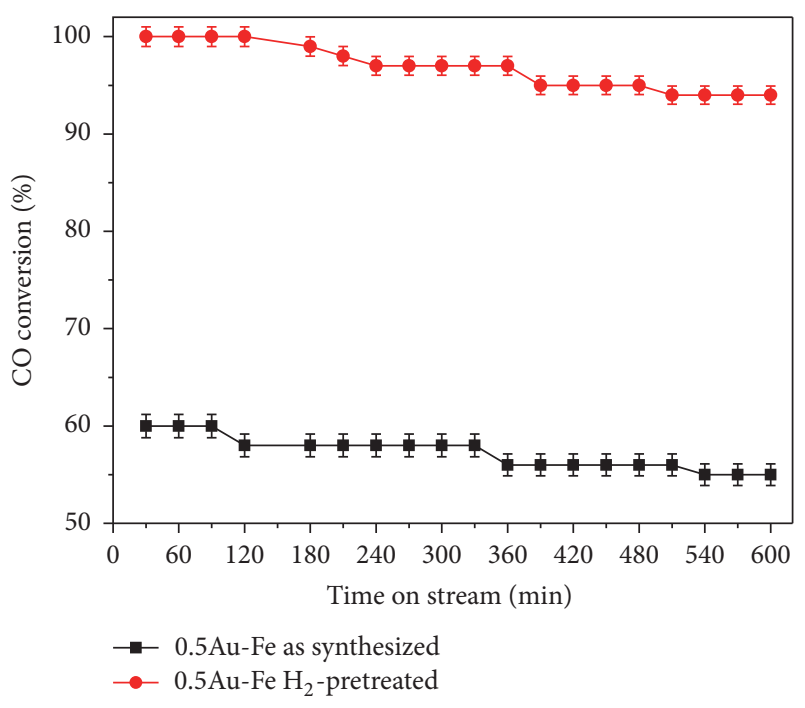

FIgURE 11: Time on stream analysis of $0.5 \mathrm{Au}-\mathrm{Fe}$ catalysts (reaction conditions: weight of catalyst $0.5 \mathrm{~g}$; total flow rate $1000 \mathrm{~mL} \mathrm{~min}{ }^{-1}$; feed composition: $100 \mathrm{ppm} \mathrm{CO/air;} \mathrm{T:} 293 \mathrm{~K}$; GHSV $=120,000 \mathrm{~mL} \mathrm{~g}^{-1} \mathrm{~h}^{-1}$ ).

catalysts for $\mathrm{CO}$ oxidation. Liu et al. [52] reported that oxygen atoms of the $\mathrm{Fe}_{2} \mathrm{O}_{3}$ lattice do not participate in the reaction at room temperature. The catalytic oxidation takes place via the interaction of $\mathrm{CO}$ adsorbed on the surface of the $\mathrm{Au}$ particles and $\mathrm{O}_{2}$ adsorbed on the adjacent oxygen vacancies on the surface of the support. However, Tripathy et al. [53] studied the $\mathrm{CO}$ oxidation using the microcalorimetry technique and concluded that the lattice oxygen of $\mathrm{Fe}_{2} \mathrm{O}_{3}$ does play an important role in the reaction. Later, Guczi et al. [54] proposed that the high activity of $\mathrm{Au}-\mathrm{Fe}_{2} \mathrm{O}_{3}$ samples for $\mathrm{CO}$ oxidation was due to the high $\mathrm{O}_{2}$ adsorption over the $\mathrm{Fe}_{2} \mathrm{O}_{3}$, which acted as the oxygen reservoir during the reaction. Okumura and Haruta [9] observed that Au metallic species in $\mathrm{Au} / \alpha-\mathrm{Fe}_{2} \mathrm{O}_{3}$ catalysts are very active. However, Hutchings et al. [10] and Khoudiakov et al. [11] reported that $\mathrm{Au}$ cation species in the $\mathrm{Au} / \mathrm{Fe}_{2} \mathrm{O}_{3}$ catalysts are responsible for activity in CO oxidation. Park and Lee [12] also reported that oxidized gold species are more active than metallic $\mathrm{Au}$. These authors indicated that reduction of Au oxide to metallic Au could be one of the reasons for the deactivation of $\mathrm{Au} / \mathrm{Fe}_{2} \mathrm{O}_{3}$ catalysts in $\mathrm{CO}$ oxidation. In addition, they observed that $\mathrm{Au}$ oxide and iron oxide reduction peaks shifted to a higher temperature in the $\mathrm{H}_{2}$-TPR patterns, indicating that the strong interaction between $\mathrm{Au}$ species and $\mathrm{Fe}_{2} \mathrm{O}_{3}$ support. Very recently, Luengnaruemitchai et al. [55] reported a decrease of CO conversion from $95 \%$ to $44 \%$ at $333 \mathrm{~K}$ after oxygen pretreatment of the catalyst. It was suggested that the reason for the decrease of activity is the formation of surface oxygen species on the Au surface after the catalyst was treated with oxygen at low temperatures [56]. As we know, the reaction of $\mathrm{CO}$ with $\mathrm{O}_{2}$ requires both $\mathrm{CO}$ and $\mathrm{O}_{2}$ to be adsorbed on the catalyst surface. However, the reaction temperature for $\mathrm{CO}$ oxidation is low $(273 \mathrm{~K}$ to $333 \mathrm{~K}$ ), so the surface oxygen species will not be desorbed at these temperatures, and the oxygen species at the surface were occupying reactive sites. Thus, the strongly adsorbed surface oxygen species blocks the adsorption and diffusion of weakly adsorbed surface oxygen resulting in a decrease of $\mathrm{CO}$ oxidation activity. For this reason, we pretreated $\mathrm{Au}-\mathrm{Fe}$ catalysts with $\mathrm{H}_{2}$ at $353 \mathrm{~K}$ for $1 \mathrm{~h}$ to remove surface oxygen species.

Okumura and Haruta [9] also indicated that spherical gold particles, which are strongly attached to the support by their flat planes, could be one of the reasons for their high activity in catalytic oxidation. Grunwaldt et al. [57] also made a very similar suggestion that the interaction of gold particles with the $\mathrm{Fe}_{2} \mathrm{O}_{3}$ support is physically and electronically strong because the shape of gold particles is spherical and flattened on one side. On the basis of catalyst preparation conditions adopted in our study and characterization results, we can suggest that $\mathrm{Au}^{3+}$ ions in the gold precursor deposited on the surface of the support and became $\mathrm{Au}^{\delta+}$ due to the interaction between them. In case of catalysts which have lower Au loading (0.1 wt.\% to $0.5 \mathrm{wt} . \%)$, the extent of interaction is high, which led to the formation of highly dispersive spherical Au particles (XRD, TEM, and XPS results). Further increase of Au loading to $1.0 \mathrm{wt} . \%$ resulted in the formation of agglomerated Au particles (XRD results). It was suggested that the agglomeration of Au particles could happen due to atom/clusters diffusion along the support and Ostwald ripening, where large particles grow at the expense of smaller particles due to the atomization and diffusion between particles [58].

The calcined $\mathrm{Au}-\mathrm{Fe}$ nanocomposite samples contained both metallic $\mathrm{Au}$ and oxidic $\mathrm{Au}-\mathrm{Fe}$ interactive species. It was already proven that both $\mathrm{Au}^{\mathrm{III}}$ and $\mathrm{Au}^{0}$ species are active for $\mathrm{CO}$ oxidation [59]. After the catalyst was exposed to $\mathrm{CO} / \mathrm{O}_{2}$ mixture, the $\mathrm{Au}^{\delta+} / \mathrm{Au}^{0}$ ratio was decreased and after sufficiently long exposure only metallic Au will remain. It appears that the decrease in the activity that we and other researchers [11] observed with just calcined catalysts is due to the $\mathrm{Au}^{\mathrm{III}}$ to $\mathrm{Au}^{0}$ transformation.

The superior catalytic activity of the $0.5 \mathrm{Au}-\mathrm{Fe}$ catalyst could be explained as due to the formation of small $\mathrm{Au}$ Fe particles dispersed on the support structure and also possessing of large surface area (Table 1). It was previously reported that the $\mathrm{CO}$ oxidation reaction normally takes place at the interface between gold cationic species and the iron sites [60]. The size of the interface between the $\mathrm{Au}$ particles and $\mathrm{Fe}_{2} \mathrm{O}_{3}$ is an important factor influencing the catalytic response of supported Au catalysts in reaction of $\mathrm{CO}$ oxidation [61]. It is generally accepted that the oxidation of $\mathrm{CO}$ over transition-metal oxides such as $\mathrm{Fe}_{2} \mathrm{O}_{3}, \mathrm{MnO}_{2}$, and $\mathrm{CuO}$ follows a Mars-van Krevelen mechanism, in which lattice oxygen is involved in $\mathrm{CO}$ oxidation and the reduced surface of the catalyst is reoxidized by $\mathrm{CO} / \mathrm{O}_{2}$ feed mixture [62]. A high activity for $\mathrm{CO}$ oxidation can be achieved due to quick redox cycle through the spillover of reactive oxygen from the support to $\mathrm{Au}$ [63]. The XRD pattern of the spent $0.5 \mathrm{Au}-\mathrm{Fe}$ catalyst (not shown) showed diffraction peaks due to hematite phase as a fresh sample, and no new diffractions peak due to Au oxides appeared. This observation clearly 
indicated that the Au-Fe catalysts have not undergone any structural changes under adapted reaction conditions.

\section{Conclusions}

In summary, we have successfully synthesized a mesoporous $\alpha-\mathrm{Fe}_{2} \mathrm{O}_{3}$ material by simple hydrothermal method and the obtained $\alpha-\mathrm{Fe}_{2} \mathrm{O}_{3}$ was used to prepare Au-Fe nanocomposites with different Au loadings (0.1 to $1.0 \mathrm{wt} \%$ ). The calcined and $\mathrm{H}_{2}$-pretreated $\mathrm{Au}$-Fe nanocomposite samples showed a high catalytic activity for CO oxidation at low temperatures. CO was fully converted at reaction temperature as low as $313 \mathrm{~K}$ over the $\mathrm{H}_{2}$-pretreated catalysts. Catalytic performance of $\mathrm{Au}-\mathrm{Fe}$ nanocomposites depends strongly on Au loading, among which $0.5 \mathrm{wt}$.\% Au displayed the best performance. Further increase of the Au loading resulted in a decrease of $\mathrm{CO}$ oxidation activity. The characterization results suggest that both metallic $\mathrm{Au}$ and partially oxidized Au species are responsible for the catalytic oxidation of $\mathrm{CO}$ in addition to the $\mathrm{Au}$ particle size. The mesoporous nature with high specific surface area of the Au-Fe nanocomposites is also a contributing factor for the observed high catalytic activity. The Au-Fe nanocomposites also showed good reproducibility and stability in $\mathrm{CO}$ oxidation. The Au-Fe nanocomposites showed higher $\mathrm{CO}$ oxidation activity than other Au supported catalysts reported in the literature mainly due to enhanced interaction between $\mathrm{Au}$ nanoparticles and the mesoporous $\mathrm{Fe}_{2} \mathrm{O}_{3}$ support.

\section{Conflicts of Interest}

The authors declare that there are no conflicts of interest regarding the publication of this paper.

\section{Acknowledgments}

This project was funded by the Deanship of Scientific Research (DSR) at King Abdulaziz University, Jeddah, under Grant no. 17/130/1435. The authors therefore acknowledge with thanks the DSR for the technical and financial support.

\section{References}

[1] G. J. Hutchings and J. K. Edwards, Metal Nanoparticles and Nanoalloys, vol. 3, 2012.

[2] R. F. Coburn, "Mechanisms of carbon monoxide toxicity," Preventive Medicine, vol. 8, no. 3, pp. 310-322, 1979.

[3] J. C. Amphlett, K. A. M. Creber, J. M. Davis, R. F. Mann, B. A. Peppley, and D. M. Stokes, "Hydrogen production by steam reforming of methanol for polymer electrolyte fuel cells," International Journal of Hydrogen Energy, vol. 19, no. 2, pp. 131137, 1994.

[4] Y. Nishihata, J. Mizuki, T. Akao et al., "Self-regeneration of a Pdperovskite catalyst for automotive emissions control," Nature, vol. 418, no. 6894, pp. 164-167, 2002.

[5] M. M. Schubert, S. Hackenberg, A. C. Van Veen, M. Muhler, V. Plzak, and J. Behm, "CO oxidation over supported gold catalysts-'Inert' and 'active' support materials and their role for the oxygen supply during reaction," Journal of Catalysis, vol. 197, no. 1, pp. 113-122, 2001.

[6] M. Haruta, N. Yamada, T. Kobayashi, and S. Iijima, "Gold catalysts prepared by coprecipitation for low-temperature oxidation of hydrogen and of carbon monoxide," Journal of Catalysis, vol. 115, pp. 301-309, 1989.

[7] K. Narasimharao, A. Al-Shehri, and S. Al-Thabaiti, "Porous Ag-Fe2O3 nanocomposite catalysts for the oxidation of carbon monoxide," Applied Catalysis A: General, vol. 505, pp. 431-440, 2015.

[8] R. Rioux, Model Systems in Catalysis, Springer Science Business, New York, NY, USA, November 2009.

[9] M. Okumura and M. Haruta, "Preparation of supported gold catalysts by liquid-phase grafting of gold acethylacetonate for low-temperature oxidation of $\mathrm{CO}$ and of $\mathrm{H}_{2}$," Chemistry Letters, no. 4, pp. 396-397, 2000.

[10] G. J. Hutchings, M. S. Hall, A. F. Carley et al., "Role of gold cations in the oxidation of carbon monoxide catalyzed by iron oxide-supported gold," Journal of Catalysis, vol. 242, no. 1, pp. 71-81, 2006.

[11] M. Khoudiakov, M. C. Gupta, and S. Deevi, " $\mathrm{Au} / \mathrm{Fe}_{2} \mathrm{O}_{3}$ nanocatalysts for CO oxidation: a comparative study of depositionprecipitation and coprecipitation techniques," Applied Catalysis A: General, vol. 291, no. 1-2, pp. 151-161, 2005.

[12] E. D. Park and J. S. Lee, "Effects of pretreatment conditions on CO oxidation over supported Au catalysts," Journal of Catalysis, vol. 186, pp. 1-11, 1999.

[13] A. Luengnaruemitchai, D. T. K. Thoa, S. Osuwan, and E. Gulari, "A comparative study of $\mathrm{Au} / \mathrm{MnO}_{x}$ and $\mathrm{Au} / \mathrm{FeO}_{x}$ catalysts for the catalytic oxidation of CO in hydrogen rich stream," International Journal of Hydrogen Energy, vol. 30, no. 9, pp. 981987, 2005.

[14] S.-W. Cao, J. Fang, M. M. Shahjamali et al., "In situ growth of Au nanoparticles on $\mathrm{Fe}_{2} \mathrm{O}_{3}$ nanocrystals for catalytic applications," CrystEngComm, vol. 14, no. 21, pp. 7229-7235, 2012.

[15] P. Li and D. E. Miser, "The removal of carbon monoxide by iron oxide nanoparticles," Applied Catalysis B: Environmental, vol. 43, pp. 151-162, 2003.

[16] P. Llewellyn, Adsorption by Powders and Porous Solids: Principles, Methodology and Applications, 2014.

[17] H. Liang, K. Liu, and Y. Ni, "Synthesis of mesoporous $\alpha-\mathrm{Fe}_{2} \mathrm{O}_{3}$ via sol-gel methods using cellulose nano-crystals (CNC) as template and its photo-catalytic properties," Materials Letters, vol. 159, pp. 218-220, 2015.

[18] S. G. Hosseini, R. Ahmadi, A. Ghavi, and A. Kashi, "Synthesis and characterization of $\alpha-\mathrm{Fe}_{2} \mathrm{O}_{3}$ mesoporous using SBA-15 silica as template and investigation of its catalytic activity for thermal decomposition of ammonium perchlorate particles," Powder Technology, vol. 278, pp. 316-322, 2015.

[19] C. K. Costello, M. C. Kung, H. S. Oh, Y. Wang, and H. H. Kung, "Nature of the active site for $\mathrm{CO}$ oxidation on highly active $\mathrm{Au} / \gamma-\mathrm{Al}_{2} \mathrm{O}_{3}$," Applied Catalysis A: General, vol. 232, pp. 159-168, 2001.

[20] M. C. Kung, R. J. Davis, and H. H. Kung, "Understanding aucatalyzed low-temperature CO oxidation," Journal of Physical Chemistry C, vol. 111, no. 32, pp. 11767-11775, 2007.

[21] Z. Zhong, J. Ho, J. Teo, S. Shen, and A. Gedanken, "Synthesis of porous $\alpha-\mathrm{Fe}_{2} \mathrm{O}_{3}$ nanorods and deposition of very small gold particles in the pores for catalytic oxidation of CO," Chemistry of Materials, vol. 19, no. 19, pp. 4776-4782, 2007. 
[22] S. N. Basahel, M. Mokhtar, E. H. Alsharaeh, T. T. Ali, H. A. Mahmoud, and K. Narasimharao, "Physico-chemical and catalytic properties of mesoporous $\mathrm{CuO}-\mathrm{ZrO}_{2}$ catalysts," Catalysts, vol. 6, no. 4, article 57, 2016.

[23] Y. Liu, L. Chen, J. Hu, J. Li, and R. Richards, " $\mathrm{TiO}_{2}$ nanoflakes modified with gold nanoparticles as photocatalysts with high activity and durability under near UV irradiation," Journal of Physical Chemistry C, vol. 114, pp. 1641-1645, 2010.

[24] T. Fujitani and I. Nakamura, "Mechanism and active sites of the oxidation of $\mathrm{CO}$ over $\mathrm{Au} / \mathrm{TiO}_{2}$," Angewandte Chemie - International Edition, vol. 50, no. 43, pp. 10144-10147, 2011.

[25] T. V. Choudhary and D. W. Goodman, "Oxidation catalysis by supported gold nano-clusters," Topics in Catalysis, vol. 21, pp. 25-34, 2002.

[26] Y. P. He, Y. M. Miao, C. R. Li et al., "Size and structure effect on optical transitions of iron oxide nanocrystals," Physical Review B - Condensed Matter and Materials Physics, vol. 71, no. 12, Article ID 125411, 2005.

[27] H. Zhu, E. Zhu, G. Ou, L. Gao, and J. Chen, " $\mathrm{Fe}_{3} \mathrm{O}_{4}-\mathrm{Au}$ and $\mathrm{Fe}_{2} \mathrm{O}_{3}$-Au hybrid nanorods: layer-by-layer assembly synthesis and their magnetic and optical properties," Nanoscale Research Letters, vol. 5, no. 11, pp. 1755-1761, 2010.

[28] A. S. Reddy, C.-Y. Chen, C. C. Chen et al., "Synthesis and characterization of $\mathrm{Fe} / \mathrm{CeO}_{2}$ catalysts: epoxidation of cyclohexene," Journal of Molecular Catalysis A: Chemical, vol. 318, no. 1-2, pp. 60-67, 2010.

[29] K. S. W. Sing, D. H. Everett, R. A. W. Haul et al., "Reporting physisorption data for gas/solid systems with special reference to the determination of surface area and porosity (recommendations 1984)," Pure and Applied Chemistry, vol. 57, pp. 603-619, 1985.

[30] K. S. W. Sing, "Reporting physisorption data for gas/solid systems with special reference to the determination of surface area and porosity (provisional)," Pure and Applied Chemistry, vol. 54, pp. 2201-2218, 1982.

[31] J. Huang, W. L. Dai, and K. N. Fan, "Remarkable support crystal phase effect in $\mathrm{Au} / \mathrm{FeO}_{x}$ catalyzed oxidation of 1,4-butanediol to $\gamma$-butyrolactone," Journal of Catalysis, vol. 266, pp. 228-235, 2009.

[32] M. S. Chen and D. W. Goodman, "The structure of catalytically active gold on titania," Science, vol. 306, no. 5694, pp. 252-255, 2004.

[33] S. Arrii, F. Morfin, A. J. Renouprez, and J. L. Rousset, “Oxidation of $\mathrm{CO}$ on gold supported catalysts prepared by laser vaporization: direct evidence of support contribution," Journal of the American Chemical Society, vol. 126, no. 4, pp. 1199-1205, 2004.

[34] C. L. Peza-Ledesma, L. Escamilla-Perea, R. Nava, B. Pawelec, and J. L. G. Fierro, "Supported gold catalysts in SBA-15 modified with $\mathrm{TiO}_{2}$ for oxidation of carbon monoxide," Applied Catalysis A: General, vol. 375, no. 1, pp. 37-48, 2010.

[35] H. Y. Lin and Y. W. Chen, "Low-temperature CO oxidation on $\mathrm{Au} / \mathrm{Fe}_{x} \mathrm{O}_{y}$ catalysts," Industrial \& Engineering Chemistry Research, vol. 44, no. 13, pp. 4569-4576, 2005.

[36] W. S. Epling, G. B. Hoflund, J. F. Weaver, S. Tsubota, and M. Haruta, "Surface characterization study of $\mathrm{Au} / \alpha-\mathrm{Fe}_{2} \mathrm{O}_{3}$ and $\mathrm{Au} / \mathrm{Co}_{3} \mathrm{O}_{4}$ low-temperature $\mathrm{CO}$ oxidation catalysts," The Journal of Physical Chemistry, vol. 100, pp. 9929-9934, 1996.

[37] C. R. Brundle, "Oxygen adsorption and thin oxide formation at iron surfaces: an XPS/UPS study," Surface Science, vol. 66, no. 2, pp. 581-595, 1977.
[38] J. F. Moulder, W. F. Stickle, P. E. Sobol, and K. D. Bomben, Handbook of X-Ray Photoelectron Spectroscopy, Perkin-Elmer, Waltham, Mass, USA, 1992.

[39] B. Aeijelts Averink Silberova, G. Mul, M. Makkee, and J. A. Moulijn, "DRIFTS study of the water-gas shift reaction over $\mathrm{Au} / \mathrm{Fe}_{2} \mathrm{O}_{3}$," Journal of Catalysis, vol. 243, no. 1, pp. 171-182, 2006.

[40] S. A. C. Carabineiro, N. Bogdanchikova, P. B. Tavares, and J. L. Figueiredo, "Nanostructured iron oxide catalysts with gold for the oxidation of carbon monoxide," RSC Advances, vol. 2, no. 7, pp. 2957-2965, 2012.

[41] A. Venugopal and M. S. Skurrell, "Low temperature reductive pretreatment of $\mathrm{Au} / \mathrm{Fe}_{2} \mathrm{O}_{3}$ catalysts, TPR/TPO studies and behaviour in the water-gas shift reaction," Applied Catalysis A: General, vol. 258, no. 2, pp. 241-249, 2004.

[42] A. S. K. Hashmi and G. J. Hutchings, "Gold catalysis," Angewandte Chemie-International Edition, vol. 45, no. 47, pp. 78967936, 2006.

[43] K. Qian, W. Zhang, H. Sun et al., "Hydroxyls-induced oxygen activation on 'inert' Au nanoparticles for low-temperature CO oxidation," Journal of Catalysis, vol. 277, no. 1, pp. 95-103, 2011.

[44] N. W. Cant, P. C. Hicks, and B. S. Lennon, "Steady-state oxidation of carbon monoxide over supported noble metals with particular reference to platinum," Journal of Catalysis, vol. 54, no. 3, pp. 372-383, 1978.

[45] Tana, F. Wang, H. Li, and W. Shen, "Influence of Au particle size on $\mathrm{Au} / \mathrm{CeO}_{2}$ catalysts for $\mathrm{CO}$ oxidation," Catalysis Today, vol. 175, no. 1, pp. 541-545, 2011.

[46] W. Zhang, X. Lu, W. Zhou, F. Wu, and J. Li, "Mesoporous iron oxide-silica supported gold catalysts for low-temperature CO oxidation," Chinese Science Bulletin, vol. 59, pp. 4008-4013, 2014.

[47] N. Weiher, E. Bus, L. Delannoy et al., "Structure and oxidation state of gold on different supports under various $\mathrm{CO}$ oxidation conditions," Journal of Catalysis, vol. 240, no. 2, pp. 100-107, 2006.

[48] A. A. Herzing, C. J. Kiely, A. F. Carley, P. Landon, and G. J. Hutchings, "Identification of active gold nanoclusters on iron oxide supports for CO oxidation," Science, vol. 321, no. 5894, pp. 1331-1335, 2008.

[49] P. Liu and J. Rodriguez, "Water-gas-shift reaction on metal nanoparticles and surfaces," The Journal of Chemical Physics, vol. 126, pp. 164705-164712, 2007.

[50] N. A. Hodge, C. J. Kiely, R. Whyman et al., "Microstructural comparison of calcined and uncalcined gold/iron-oxide catalysts for low-temperature CO oxidation," Catalysis Today, vol. 72, no. 1-2, pp. 133-144, 2002.

[51] W. Deng, C. Carpenter, N. Yia, and M. F. Stephanopoulos, "Comparison of the activity of $\mathrm{Au} / \mathrm{CeO}_{2}$ and $\mathrm{Au} / \mathrm{Fe}_{2} \mathrm{O}_{3}$ catalysts for the CO oxidation and the water-gas shift reactions," Topics in Catalysis, vol. 44, no. 1, pp. 199-208, 2007.

[52] H. Liu, A. I. Kozlov, A. P. Kozlova, T. Shido, and Y. Iwasawa, "Active oxygen species and reaction mechanism for low-temperature $\mathrm{CO}$ oxidation on an $\mathrm{Fe}_{2} \mathrm{O}_{3}$-supported $\mathrm{Au}$ catalyst prepared from $\mathrm{Au}\left(\mathrm{PPh}_{3}\right)\left(\mathrm{NO}_{3}\right)$ and as-precipitated iron hydroxide," Physical Chemistry Chemical Physics, vol. 1, no. 11, pp. 2851-2860, 1999.

[53] A. K. Tripathy, V. S. Kamble, and N. M. Gupta, "Microcalorimetry, adsorption, and reaction studies of $\mathrm{CO}, \mathrm{O}_{2}$, and $\mathrm{CO}+\mathrm{O}_{2}$ over $\mathrm{Au} / \mathrm{Fe}_{2} \mathrm{O}_{3}, \mathrm{Fe}_{2} \mathrm{O}_{3}$, and polycrystalline gold catalysts," Journal of Catalysis, vol. 187, pp. 332-342, 1999.

[54] L. Guczi, D. Horváth, Z. Pászti, and G. Petõ, "Effect of treatments on gold nanoparticles: Relation between morphology, 
electron structure and catalytic activity in CO oxidation," Catal Today, vol. 72, no. 1-2, pp. 101-105, 2002.

[55] A. Luengnaruemitchai, K. Srihamat, C. Pojanavaraphan, and R. Wanchanthuek, "Activity of $\mathrm{Au} / \mathrm{Fe}_{2} \mathrm{O}_{3}-\mathrm{TiO}_{2}$ catalyst for preferential CO oxidation," International Journal of Hydrogen Energy, vol. 40, no. 39, pp. 13443-13455, 2015.

[56] Z. Qu, W. Huang, S. Zhou, H. Zheng, X. Liu, and M. Cheng, "Enhancement of the catalytic performance of supported-metal catalysts by pretreatment of the support," Journal of Catalysis, vol. 234, pp. 33-36, 2005.

[57] J.-D. Grunwaldt, M. Maciejewski, O. S. Becker, P. Fabrizioli, and A. Baiker, "Comparative study of $\mathrm{Au} / \mathrm{TiO}_{2}$ and $\mathrm{Au} / \mathrm{ZrO}_{2}$ catalysts for low-temperature CO oxidation," Journal of Catalysis, vol. 186, no. 2, pp. 458-469, 1999.

[58] C. C. Chusuei, X. Lai, K. Luo, and D. W. Goodman, "Modeling heterogeneous catalysts: metal clusters on planar oxide supports," Topics in Catalysis, vol. 14, no. 1-4, pp. 71-83, 2000.

[59] A. M. Visco, F. Neri, G. Neri, A. Donato, C. Milone, and S. Galvagno, "X-ray photoelectron spectroscopy of $\mathrm{Au} / \mathrm{Fe}_{2} \mathrm{O}_{3}$ catalysts," Physical Chemistry Chemical Physics, vol. 1, no. 11, pp. 2869-2873, 1999.

[60] R. E. Ramírez-Garza, B. Pawelec, T. A. Zepeda, and A. MartínezHernández, "Total CO oxidation over Fe-containing Au/HMS catalysts: effects of gold loading and catalyst pretreatment," Catalysis Today, vol. 172, no. 1, pp. 95-102, 2011.

[61] T. Hayashi, K. Tanaka, and M. Haruta, "Selective vapor-phase epoxidation of propylene over $\mathrm{Au} / \mathrm{TiO}_{2}$ catalysts in the presence of oxygen and hydrogen," Journal of Catalysis, vol. 178, no. 2, pp. 566-575, 1998.

[62] S. Minicò, S. Scirè, C. Crisafulli, and S. Galvagno, "Influence of catalyst pretreatments on volatile organic compounds oxidation over gold/iron oxide," Applied Catalysis B: Environmental, vol. 34, no. 4, pp. 277-285, 2001.

[63] L. Li, A. Wang, B. Qiao et al., "Origin of the high activity of $\mathrm{Au} / \mathrm{FeO}_{x}$ for low-temperature $\mathrm{CO}$ oxidation: direct evidence for a redox mechanism," Journal of Catalysis, vol. 299, pp. 90-100, 2013. 

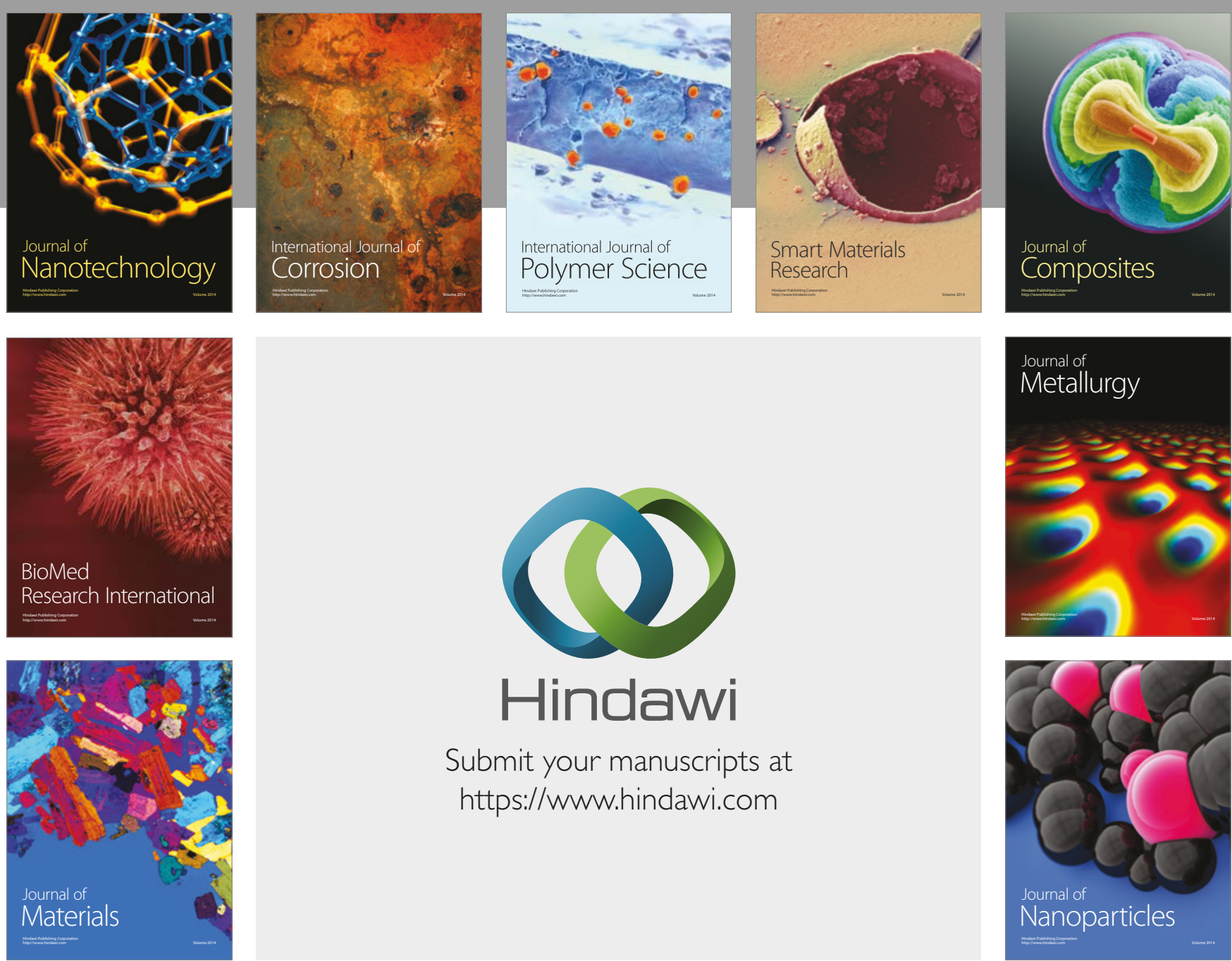

\section{Hindawi}

Submit your manuscripts at

https://www.hindawi.com
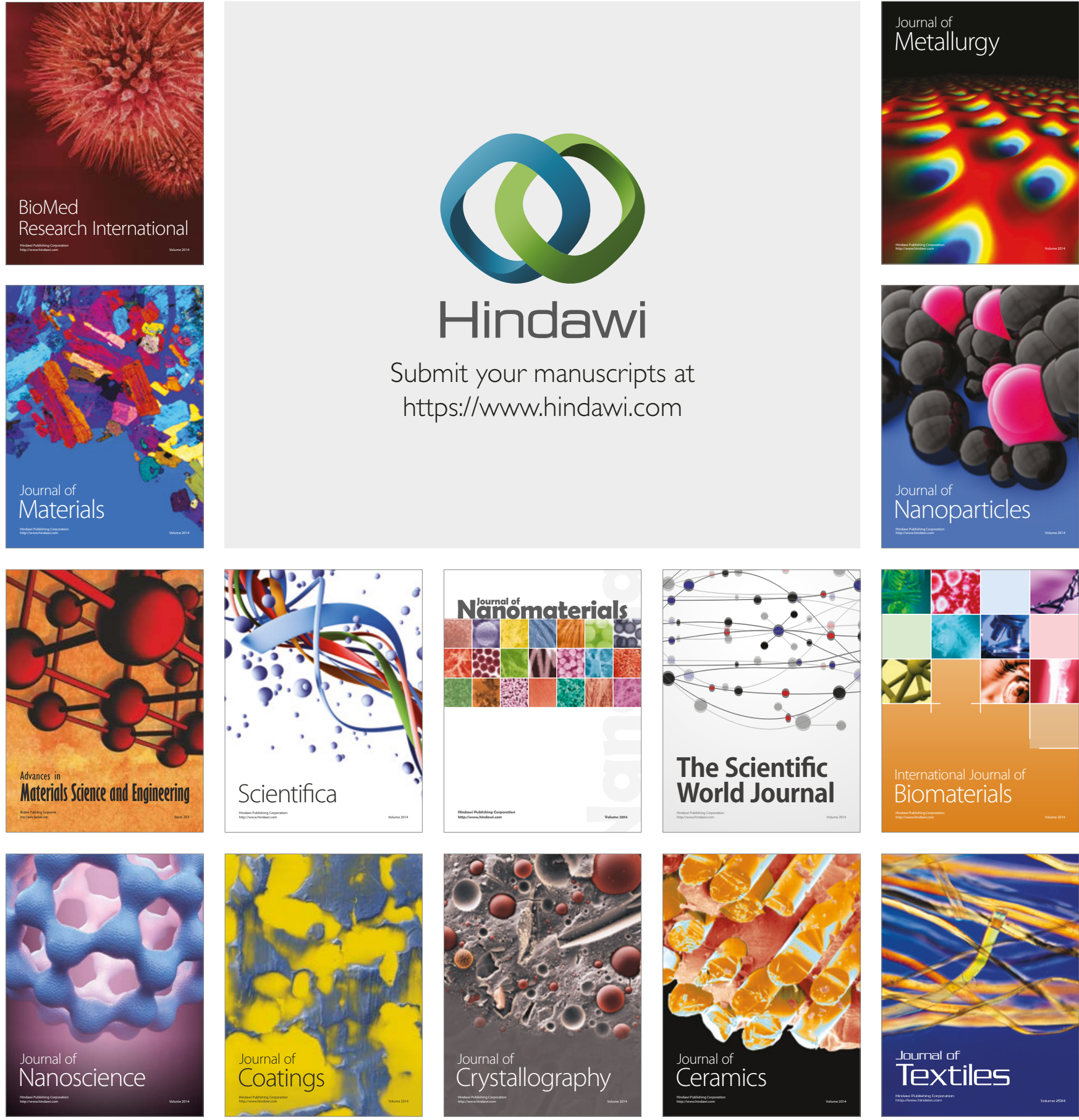

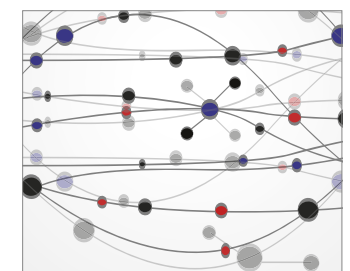

The Scientific World Journal
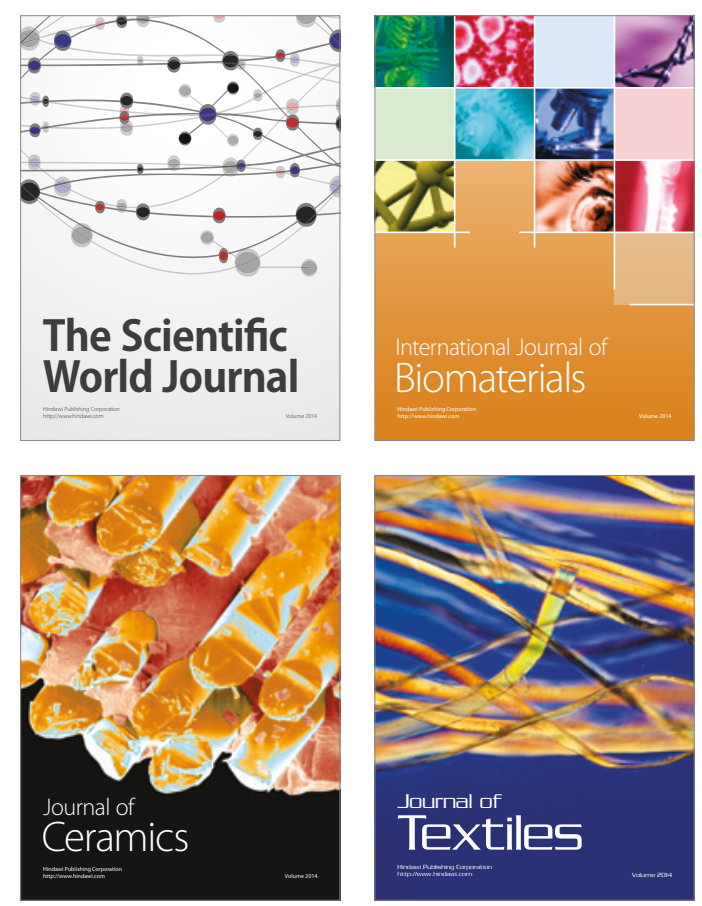